ICTD Working Paper 6

\section{Donors, Aid and Taxation in Developing Countries: An Overview}

Wilson Prichard, Jean-François Brun and Oliver Morrissey

September 2012 
Donors, Aid and Taxation in Developing Countries: An Overview

Wilson Prichard, Jean-François Brun and Oliver Morrissey

ICTD Working Paper 6

First published by the Institute of Development Studies in September 2012

(C) Institute of Development Studies 2012

ISBN 978-1-78118-092-1

A catalogue record for this publication is available from the British Library.

All rights reserved. Reproduction, copy, transmission, or translation of any part of this publication may

be made only under the following conditions:

- with the prior permission of the publisher; or

- with a licence from the Copyright Licensing Agency Ltd., 90 Tottenham Court Road, London W1P 9HE, UK,

or from another national licensing agency; or

- under the terms set out below.

This publication is copyright, but may be reproduced by any method without fee for teaching or nonprofit purposes, but not for resale. Formal permission is required for all such uses, but normally will be granted immediately. For copying in any other circumstances, or for reuse in other publications, or for translation or adaptation, prior written permission must be obtained from the publisher and a fee may be payable.

Available from:

Communications Unit,

Institute of Development Studies,

Brighton BN1 9RE, UK

Tel: +44 (0) 1273915637 Fax: +44 (0) 1273621202

E-mail: bookshop@ids.ac.uk

Web: www.ids.ac.uk/ids/bookshop

IDS is a charitable company limited by guarantee and registered in England (No. 877338) 


\title{
Donors, Aid and Taxation in Developing Countries: An Overview ${ }^{1}$
}

\author{
Wilson Prichard, Jean-François Brun and Oliver Morrissey
}

\section{Summary}

Recent years have witnessed rapidly growing donor interest in tax issues in the developing world. This reflects a concern with revenue collection to finance public spending, but also recognition of the centrality of taxation to growth, redistribution and broader state-building and governance goals. Against this backdrop, this paper identifies a series of key issues that demand attention if donors are to improve the quality of their support for tax reform. The focus is not, primarily, on the technical design of tax interventions, but, instead, on seven 'big picture' considerations for the design of donor programmes: (a) supporting local leadership of reform efforts; (b) incorporating more systematic political economy analysis into the design and implementation of reform programmes; (c) designing tax reform programmes that seek to foster broader linkages between taxation, state-building and governance; (d) paying careful attention to the complexity of the relationship between aid and tax effort; (e) better designing tax-related conditionality, particularly by developing a more nuanced set of performance indicators; ( $f$ ) ensuring the effective coordination of donor interventions; and $(\mathrm{g})$ paying greater attention to the international policy context, and particularly the role of tax exemptions for donor projects, tax havens and tax evasion by multinational corporations (MNCs) in undermining developing country tax systems.

Keywords: taxation; tax reform; foreign aid; donors; tax effort; conditionality.

Wilson Prichard is Assistant Professor of Political Science and Global Affairs at the University of Toronto and co-Research Director of the International Centre for Tax and Development.

Jean-François Brun is Associate Professor at Centre d'Études et de Recherches sur le Développement International (CERDI), Université d'Auvergne.

Oliver Morrissey is Professor of Development Economics at the University of Nottingham.

This paper has been written with financial support from the International Centre for Tax and Development (ICTD), which receives funding from the Department for International Development (DfID) and Norwegian Agency for Development Cooperation (Norad). The paper has benefited from comments received from participants at the ICTD annual meeting in June 2011. Special thanks are due to Ben Dickinson and Sue Unsworth for excellent comments on an earlier draft. 


\section{Contents}

Summary 3

Introduction $\quad 5$

$1 \quad$ Strengthening donor-supported tax reform 4

$\begin{array}{lll}1.1 & \text { Reform and convergence in the developing world } & 7\end{array}$

1.2 Deepening tax reform: local context and the political economy of reform

1.3 Broadening the agenda: components of a governance-focused tax reform agenda

2 Aid flows, incentives and tax collection: tracing complex linkages

2.1 Aid and tax effort: existing findings, challenges and debates

2.2 Aid and tax effort: a more complex relationship

$3 \quad$ The growth of conditionality: key questions and messages 17

3.1 Is tax-related conditionality effective? 18

3.2 Designing conditionality and the importance of better indicators 20

3.3 Alternative forms of conditionality

4 Beyond tax reform: additional issues for donors 24

4.1 Donor proliferation 24

4.2 The tax treatment of aid-funded goods and services 24

4.3 Donors, tax havens and international tax evasion 25

$\begin{array}{lll}5 & \text { Conclusions } & 27\end{array}$

Appendix: Existing evidence linking aid and tax effort 29

References 33 


\section{Introduction}

The past decade in particular has witnessed a significant increase in measures to reform and strengthen tax systems in the developing world. This growing interest is reflected in increased funding for tax-related development assistance, ${ }^{2}$ a growing number of international forums, organisations and meetings looking at tax issues; ${ }^{3}$ and the growing prominence of tax-related conditionality in large International Monetary Fund (IMF) assistance programmes. ${ }^{4}$ In broad terms this reflects growing concern with revenue collection to finance public spending, but also recognition of the centrality of taxation to growth, redistribution and broader state-building and governance goals.

This is not to suggest donor involvement with tax reform is in any sense new. The reform of trade taxes was a major component of structural adjustment reforms in the 1980s and 1990s, while external assistance also figured prominently in wide-ranging reforms of tax policy and administration throughout the same period (e.g. Thirsk 1997, Gillis 1989). However, the current period of reform appears to be substantially distinct.

After a period of declining funding beginning in the latter part of the 1990 s, ${ }^{5}$ funding for taxrelated assistance appears to have increased in recent years, though it remains relatively modest as a share of total donor programmes (Barbone et al. 1999, ITC 2010). ${ }^{6}$ More importantly, perhaps, support for tax reform is becoming more diverse, in terms of both goals and actors. Whereas tax reform has traditionally been the preserve of the IMF and, to a lesser extent, the World Bank, recent years have seen expanding interest in taxation among a wide range of bilateral donors and other international agencies (ITC 2010). At the same time, the content of the tax reform agenda has arguably been broadening.. Earlier reform efforts focusing heavily on the reduction of trade taxes have been replaced with Value Added Tax (VAT) and the lowering of direct tax rates. Contemporary reform efforts are increasingly focused on relatively intrusive questions of administrative reform, while there has also been a growing interest in the links between taxation, accountability and broader state-building goals (IMF 2011).

Despite this broadening of support for tax reform, there have been few efforts to assess the direct and indirect impacts of donor activities on tax systems in the developing world (Barbone et al. 1999, IEG 2008). Much has been written about overall reform trends and progress (e.g. IMF 2011, Keen forthcoming), and such studies have frequently documented the strengths and limitations of donor activities within particular domains. Such studies have been integral, among other things, in highlighting the centrality of tax administration to reform efforts (e.g. Bird 2008). However, few studies have sought to step back from these specifics to consider a set of 'big picture' questions about how donors could better support tax systems in the developing world.

2 While this claim is widely accepted, specific data to measure the precise extent of donor funding is an ongoing problem (ITC 2010).

3 For example, recent years have seen: (a) the creation of the International Tax Dialogue in 2002, (b) the creation of two new Tropical Trust Funds at the IMF in 2011 for strengthening tax systems in the developing world, (c) the expanded involvement of the Organisation for Economic Co-operation and Development (OECD) Development Cooperation Directorate with tax issues in the developing world, (d) the highlighting of tax issues in developing countries as a key issues by the G20 in 2010-11, (e) the creation of the African Tax Administration Forum in 2009, (f) the creation of the International Centre for Tax and Development, (g) the creation of the International Tax Compact (ITC) and (h) the emergence of much more active civil society involvement in issues of taxation in the developing world.

See Gupta (2011) for an overview, as well as Bolnick and Hadler (2011) for discussion of the issue. In their review of tax-related assistance by the World Bank, Barbone et al. (1999) find that total outlays declined significantly from US\$5.1 billion during 1990-1994 to US\$3.6 billion during 1995-1998.

The OECD (2008) estimates that in 2005 only 1.7 per cent of bilateral assistance was dedicated to tax-related reform, with other elements of public financial management continuing to receive much higher priority. 
Against this backdrop, this paper does not seek to enter into longstanding debates about the technical design of tax reform programmes, though they obviously remain hugely important and have, at times, been a source of significant controversy. ${ }^{7}$ Instead, this paper seeks to highlight a series of cross-cutting issues that warrant greater attention from donors and, in some cases, much more substantial research.

Section one of the paper begins by providing a broad overview of the direct impact of donorsupported tax reform efforts on tax systems in the developing world. It argues that while donor support has enjoyed important successes, these gains have frequently been somewhat superficial. It correspondingly suggests how political economy analysis, and greater attention to the connections between taxation and broader governance outcomes, could strengthen existing donor strategies.

The sections that follow look beyond these direct effects to consider the more indirect impacts of aid, conditionality and broader donor policies on developing country tax systems. Section two focuses on the impact of aggregate aid flows on the tax collection effort in recipient countries, and argues that while access to aid may sometimes discourage tax this has certainly not always been the case. As such, greater attention needs to be paid to a more nuanced question: 'Under what conditions has aid tended to discourage tax effort, and how can this risk be mitigated?' Building on this question, section three highlights the seemingly growing role of revenue-related conditionality in large donor programmes, as a strategy both to encourage reform and to minimise the risk that aid may discourage tax effort. It argues that while there is an appropriate role for conditionality, crude conditionality, frequently based simply on the level of tax collection, may not only be ineffective, but may actually generate perverse incentives. As such, greater attention needs to be paid to the design of conditionality, and to the development of more appropriate performance measures. Section four argues that broader donor policies, particularly related to tax havens and the tax treatment of donor projects, can have major implications for developing countries, and should be a more central focus of reform efforts. Finally, section five concludes. 


\section{Strengthening donor-supported tax reform}

The starting point for thinking about the role of donors in supporting tax reform is an exploration of the broad trajectory of developing country tax systems over the past five decades. Looking at this experience, we suggest that there have been significant successes, but that these successes have too often been superficial. They have often reflected changes in formal policy and administrative rules, but significantly less meaningful reform of actual practices and outcomes. On this basis we propose that the impact of reform efforts can be deepened and broadened by paying greater attention to developing locally specific solutions, emphasising the importance of political economy analysis and seeking to foster stronger links between tax reform and broader governance and state-building goals. Cutting across these issues is a need to pay greater attention to taxation at the sub-national level. While this is small in revenue terms, it is likely to impact large segments of the population, may have important political implications, and could figure centrally in shaping accountability relationships (or their absence) between citizens and the state (Jibao and Prichard forthcoming, Fjeldstad and Heggstad forthcoming).

\subsection{Reform and convergence in the developing world}

Donor-supported tax reform efforts date to at least the 1960s, as tax experts from western countries were increasingly deployed to developing countries and figured prominently in major tax reform programmes (Gillis 1989, Thirsk 1997, Keen forthcoming, Bird 2008). By the 1980s, donor-funded technical assistance had come to encompass an increasingly standard set of recommendations and priorities. The popularisation of these 'best practices' has led Fjeldstad and Moore (2008) to refer to a 'global tax reform agenda'. The emergence of this shared agenda reflected both donor pressure and the growth of global epistemic communities of tax professionals with shared ideas about reform priorities (Fjeldstad and Moore 2008, Sanchez 2006).

While there have been no comprehensive and systematic assessments of the success of these reform programmes, ${ }^{8}$ this global reform agenda has enjoyed a relatively high degree of at least superficial success, as reflected in significant convergence in the features of developing country tax systems (Fjeldstad and Moore 2008, Sanchez 2006, IMF 2011). Keen (forthcoming) suggests that shared reform trajectories have often been driven by 'big ideas' which have shaped reform objectives across the developing world. He highlights three - VAT, revenue administrations and Large Taxpayer Units (LTUs) - though this focus on big ideas, and their proliferation, can be extended to cover a wider range of developments. ${ }^{9}$

Policy changes associated with this reform programme have notably included: (a) tax policy simplification; (b) the elimination of export taxes; (c) reduced tariffs and less reliance on trade taxes; (d) reduced income and corporate tax rates; and (e) expanded reliance on goods and services taxes and VAT in particular. These have been accompanied by administrative reforms, which, while more varied, have nonetheless had common elements across large numbers of countries. These include: (a) efforts to integrate indirect and direct tax departments; (b) functional and segmental reorganisation of administration, led by the creation of LTUs; (c) a

\footnotetext{
$8 \quad$ The World Bank did conduct a review of tax-related assistance in 1999 (Barbone et al. 1999), and this assistance was also covered by a 2008 review of public sector reform programmes (IEG 2008). These reviews have focused more narrowly on World Bank experience.

Various works by Richard Bird provide a similar overall picture of the character of reform efforts over several decades (e.g. Bird 2008).
} 
growing focus on the automation of tax administration; and (d) an emphasis on revenue agency autonomy across much of Latin America and Anglophone Africa (Bird 2008).

The breadth of this convergence in tax policy and administration alone speaks to a degree of success of external support, both directly and indirectly, through the strengthening of epistemic communities and regional professional bodies (Fjeldstad and Moore 2008, Sanchez 2006). ${ }^{10}$ While convergence does not necessarily imply that these reform trajectories have been universally appropriate, most observers contend that there have been significant gains over time, notwithstanding broad acceptance of the need for greater attention to specific local contexts and the need for local ownership (Bird 2008, Keen forthcoming).

While donor support has thus contributed to broad reform and convergence over time, many observers assert that the depth of this reform has been more limited, with changes in visible formal rules and structures often not matched by changes in practice. This very broad message is reflected in four observations.

- First, despite major changes in policy and administration, levels of tax collection have increased only marginally in recent decades (Gupta 2011, IMF 2011). ${ }^{11}$ This may understate real improvements, as revenue has largely been sustained despite a sharp decline in both trade tax revenue and income tax rates, but it also appears to reflect the relative persistence of corruption and politicisation, particularly in the lowest income countries (Bird 2008, Keen forthcoming).

- Second, while some countries have experienced rapid short-term improvements in performance, in many cases these gains have been short-lived and partially reversed when local leadership has changed or intensive external support has ebbed. ${ }^{12}$

- Third, despite often similar reform trajectories across countries, there remain highly persistent and substantial differences in revenue collection that cannot be explained by underlying economic and geographic variables alone, suggesting differences in effectiveness of the implementation of tax rules (Gupta 2007, Mkandawire 2010).

- Finally, despite significant formal changes in policy and administration, most tax administrations continue to operate according to a largely adversarial, control-based logic. Shifts towards a more co-operative mind set have been slow in most low income countries (Bird and Vazquez-Caro 2011).

The picture that emerges is of reform efforts that have yielded significant formal changes in tax regimes across the developing world, which have yielded much more modest changes in outcomes. This raises questions about how to deepen the impact of reform.

\footnotetext{
10 This began with Centro Interamericano de Administraciones Tributaria (CIAT), which was founded in 1967, and has continued more recently with the creation of the African Tax Administration Forum in 2009.

There are, of course, questions about whether expectations have at times also been set much too high, given the constraints imposed by limited tax bases. There is however still relatively clear evidence that many countries, despite formal policy and administrative reforms, are failing to fully exploit available tax bases (IMF 2011).

Prominent examples include Uganda, where revenue rose rapidly from very low levels in the early 1990s, but then reached a plateau at below 12 per cent of GDP for the decade to follow, as corruption reemerged as an issue within the Uganda Revenue Authority (Therkildsen 2004, Fjeldstad 2005); and Zambia, where tax collection rose to above 19 per cent of GDP during a donor-supported reform programme in the 1990s before declining to 16 per cent of GDP by 2006 (van Soest 2007a).
} 


\subsection{Deepening tax reform: local context and the political economy of reform}

While capacity constraints are obviously important, the paradox of significant changes in formal policy and administration but more limited changes in outcomes is a reminder that meaningful tax reform is a long and political process, and that sustaining political support for reform is both essential and very difficult. ${ }^{13}$ Without the political will to implement both policy and administrative changes, formal changes in law and structure may have limited impact or prove unsustainable. ${ }^{14}$

This message is clearly reflected in recent high-level donor evaluations of tax reform and related support. A World Bank appraisal of tax-related lending (Barbone et al. 1999) concluded that donors need to pay more careful attention to political and institutional analysis in their lending programmes. This same message was reiterated by a subsequent broader review of public sector reform efforts (IEG 2008). More recently, the IMF has prominently identified 'political will' as an essential determinant of successful reform (IMF 2011).

Unfortunately, while donors have increasingly acknowledged the centrality of politics to tax reform, this has yet to be fully reflected in actual programming. This in part reflects the fact that surprisingly little is known, from a research perspective, about the political economy of tax reform. ${ }^{15}$ Indeed, in an early work Bates (1989: 490) argued that 'no general formulas for success can be valid' because tax reform can take so many forms, and thus generate such varied political coalitions, that any actual outcome will be highly context-specific (Bird 1989, Bird 1992, Barbone et al. 1999). By extension, while the primacy of political will is increasingly well accepted, it remains less clear what this implies for donor assistance, beyond quite general messages about the determinants of successful public sector reform (Morrissey 1995). ${ }^{16}$

That said, research does provide some guidance, beginning with four broadly accepted messages:

- First, meaningful tax reform is politically difficult, as it involves relatively explicit transfers of wealth and thus generally encounters strong vested interests resistant to reform, particularly among elites.

- Second, it has historically been very difficult to mobilise support for tax reform among potential 'winners', owing both to their fragmentation, and the consequent difficulty of collective action, as well as a frequent fear of the uncertainty of tax reform (Fairfield 2010, Ascher 1989, Olson 1965).

13 In Uganda, for example, the government introduced major changes in tax policy and tax administration, including the creation of the semi-autonomous Uganda Revenue Authority (URA) in 1991. In the short-term this yielded a sharp spike in revenue and overall tax system performance, but by the late 1990s these gains had plateaued and had even been partially reversed. This is explained by Therkildsen (2004) as a function of politics: in the early 1990s the creation of the URA reflected high-level political commitment to improving the autonomy and effectiveness of the URA, but over time this political commitment eroded, and the effectiveness of the tax system declined accordingly.

14 This can to some extent be thought of as a politically focused extension of the well-known dictum that in the developing world 'tax administration is tax policy' (Casanegra de Jantsher 1990).

15 This is not, of course, to suggest that nothing is known. There has been important research on the politics of tax reform, and this research is beginning to expand quite rapidly, but it is only now beginning to be systematically translated into clear policy messages. Important country level studies of the politics of reform include, among others, Fairfield (2010, 2011), Boylan (1996), Bergman (2002, 2003), Fjeldstad (2005), Melo (2007), Lieberman (2002), Ascher (1989), Harberger (1989), Morrissey (1995), Durand and Thorp (1998) and Therkildsen (2004).

16 These include the need for political will, local ownership, contextually appropriate design and effective sequencing in implementation (Boesen 2004, Heredia and Schneider 2003, Stevens and Teggeman 2004). Morrissey (1995) addresses these issues in the context of tax reform in Tanzania. 
- Third, tax reform is more likely during periods of fiscal crisis or political transition, as during such periods elite support for reform may crystalise and resistance is more likely to be fragmented (Ascher 1989, Bates 1989, Thirsk 1997, Lieberman 2002, Mahon 2004, Sanchez 2006).

- Fourth, political instability is likely to undermine reform efforts by reducing investment by elites in long-term revenue-raising capacity, eroding voluntary compliance with taxation and undermining administrative probity (Besley and Persson 2010, Keen forthcoming, Aizenman and Jinjarak 2008).

These broad messages in turn suggest three potential lessons for reformers, though research in this area documenting specific examples is limited:

- First, there is a need to foster local ownership of reform efforts, as the stark political barriers to tax reform suggest that reform that lacks committed local leadership is very unlikely to be successfully introduced and implemented. A genuine effort to foster local ownership is likely to imply not just procedural change, but openness to local priority-setting and some degree of heterodoxy in reform objectives and strategies.

- Second, it is necessary to be opportunistic and selective in supporting reform efforts that benefit from local political support, or which, more modestly, face comparatively muted political resistance. While reform invariably implies a need to confront vested interests, during times of 'normal politics' reform that challenges many powerful interests at once is likely to be extremely difficult. By contrast, it may be possible to identify reform priorities that are comparatively 'incentive compatible', given an understanding of the alignment of powerful interests (Hassan and Prichard 2012). The timing of reform is likely to be equally important, and it is incumbent on donors to act strategically to support reform when windows of opportunity appear, rather than pushing reform even when the timing may not be propitious. All of this speaks to the need for context-specific reform priorities and design, as well as an effort to learn from successful reform strategies.

- Third, reform is more likely to be successful if citizens have greater trust in government. At some level this is beyond the scope of tax reform and beyond the control of tax reformers. However, it may be possible in some cases for reformers to tailor reform in order to enhance public trust, for example, by ensuring greater transparency in the use of funds or adherence to an inclusive process when designing and implementing reform. Some recent research has explored the potential merits of tax earmarking, particularly in environments of limited trust though earmarking also carries risks of fungibility, fiscal rigidity and manipulation, and thus warrants further study (Prichard 2010a, Bird and Jun 2005, Flores-Macías forthcoming).

Along these lines, a small body of recent research has explicitly asked if tax reform can be designed so as to build political will for reform: that is, be designed to build political support and minimise resistance (Morrissey, 1995; Fairfield 2010, 2011). In a recent paper Fairfield (2011) presents a typology of such strategies, paying particular attention to strategies to minimise elite resistance to reform. At a more general level, Prichard (2010a) argues that a focus on principles of equity, transparency and inclusiveness are frequently likely to play a role in both building support for reform and weakening likely resistance. A focus on transparency and inclusiveness holds the potential to minimise popular resistance to reform. ${ }^{17}$ A focus on equity may reinforce

17 For example, in 1995 the Ghanaian government attempted to introduce VAT without the participation of the political 
public support for reform, while simultaneously making it difficult for elites to oppose reform publicly (Ascher 1989). ${ }^{18}$ While these are only broad principles, and more research is clearly needed, they suggest both specific strategies that might be useful in a variety of cases, while also pointing to the important of well-contextualised political economy analysis.

\subsection{Broadening the agenda: components of a governance-focused tax reform agenda}

Alongside the need to deepen reform, there is also a need to pay close attention to fostering potentially positive connections between tax reform and broader governance outcomes. While researchers, donors and tax professionals have paid increasing attention to these issues, this has yet to be translated into a clear reform agenda in practice.

The impetus for such a broadening of the focus of reform efforts comes from recent research suggesting that taxation and tax reform may contribute to broader governance gains through three channels (OECD 2010, Prichard 2010a):

- Common interest processes: when governments are dependent on taxes, and therefore on the prosperity of taxpayers, they may have stronger incentives to promote economic growth (Gehlbach 2008, Bates 2001).

- State apparatus processes: dependence on taxes requires states to develop a complex bureaucratic apparatus for tax collection. This may become the leading edge of broader improvements in public administration (Bräutigam 2008, Prichard and Leonard 2010).

- Accountability and responsiveness processes: taxation may engage taxpayer-citizens collectively in politics and lead them to make claims on government for reciprocity, either through short-term conflict or long-term increases in political engagement. Governments may be compelled to respond to these citizen demands in order to enhance tax compliance and sustain state revenues (OECD 2008, Moore 2007, 2008, Prichard 2009).

While these broad ideas are increasingly accepted, it has been more difficult to translate them into a clear-cut governance-focused tax reform agenda. OECD (2010) and Prichard (2010a) outline the possible outlines of such an agenda, though there remains a need for much greater research. The key suggested elements are:

- Emphasising equity in tax enforcement, as a means to foster collective action and bargaining around tax issues rather than fragmented rent-seeking by powerful interest groups.

- Expanding transparency and tax-expenditure linkages, as a means to facilitate public engagement, trust building and bargaining around tax issues.

- A greater focus on income and property taxes, which are the most visible means to tax elites and engage them in tax bargaining (although they are also often the easiest taxes to avoid).

opposition or significant public consultation. It was met with mass public protests, which forced the repeal of the tax. Two years later the government pursued a more consultative process, bringing the political opposition on board, and was able to re-introduce the tax with minimal opposition (Osei 2000, Prichard 2009).

18 For example, in Kenya when the government sought to require that medium-sized businesses use Electronic Tax Registers as a means to increase VAT compliance it resulted in large-scale protests by those businesses. However, the government successfully framed the reform as a question of equity and fairness, which was an important reason why the striking businesses found little public support (Prichard 2010b). 
The collection of these would necessitate co-operation across government and potentially foster state capacity-building.

- A greater focus on informal sector and sub-national taxation, as they have a broad and direct incidence with the bulk of developing country populations. These have the potential to foster more broad-based engagement around tax issues, while also providing the fiscal foundation for successful decentralisation.

- Encouraging inclusive reform processes and civil society engagement, as civil society actors are likely to be crucial intermediaries in fostering state-society bargaining around taxation.

- Fostering administrative cooperation across government in order to strengthen information sharing and the potential for tax reform to be a catalyst for broader improvements in state capacity.

These proposals in many ways remain speculative, and, beyond a strong theoretical foundation, are grounded only in select case study evidence. However, that foundation of evidence is growing stronger. The policies associated with a governance-focused tax reform agenda have the added advantage of overlapping closely with policy directions emerging from broader research on the political economy of tax reform.

Of course, these ideas are not entirely new: tax reform experts, led by the IMF, have long acknowledged the importance of these issues. However, a governance-focused tax reform agenda, as described here, does nonetheless imply changes to internationally sponsored tax reform efforts. These changes would not represent a repudiation of existing strategies, but rather a reorganisation of priorities, particularly with questions about transparency, inclusiveness, equity and local government taxation taking a more prominent role in reform efforts (Prichard 2010a, OECD 2010). Achieving such a reordering of priorities would require two broad shifts within the policy community. First, it would demand an effort to 'open-up' tax reform processes to new stakeholders and more careful political analysis. Second, it would require the development of a broader range of performance indicators against which tax reform efforts are measured and judged. ${ }^{19}$ As long as tax performance is judged largely based on comparatively short-term changes in the tax ratio of Gross Domestic Product (GDP), these 'softer' elements of the reform agenda are unlikely to be given priority. Instead, there is a need for programmes that explicitly prioritise a broader range of issues - including transparency, inclusiveness and equity - if external actors are to actively seek to foster positive connections between taxation and broader governance outcomes.

Such indicators would likely include, among others, indicators capturing a more nuanced picture of the effectiveness of taxation (e.g., the number of individuals/companies registered, share of those filing taxes on time, share of those making payments on time, share of those claiming and receiving tax refunds on time); and indicators capturing elements of the relationship between taxpayers and the tax authorities (e.g., transparency of revenue and expenditure data, access to complaints procedures and adjudication, availability of support services for filing taxes, surveys of taxpayer satisfaction, time required to issue refunds and corrections). 


\section{Aid, incentives and tax collection: tracing complex linkages}

Alongside the direct impact of donors on tax systems in the developing world, there has been growing attention to the potential indirect, and unintended, impacts of aid on tax systems. Most commonly, it has been suggested that foreign aid, by providing governments with a ready source of non-tax revenue, may reduce incentives for governments to pursue politically costly domestic tax collection. This has the potential not only to reduce available financing for needed public services, but also to undermine the positive governance impacts of reliance on tax revenue (Bräutigam and Knack 2004, Moss, Pettersson and van de Walle 2006). However, while the possibility that aid may undermine domestic tax collection is clearly important, there is mounting evidence that this relationship is not robust, and thus far from guaranteed in practice. This finding is consistent with the increasing realisation that tracing direct linkages between aid flows and complex development outcomes is extremely complex and fraught with risk. As such, what follows first summarises existing evidence and then seeks to add nuance to this story, focusing on considering the specific circumstances under which aid may be likely to discourage tax effort and what can be done to mitigate this risk. The main text provides the core argument, while additional technical detail is provided in the Appendix.

\subsection{Aid and tax effort: existing findings, challenges and debates}

Most early studies of the relationship between aid and tax effort found that higher levels of aid were associated with lower tax to GDP ratios, and suggested that aid dependence may be the cause of reduced tax effort .The most influential study was that of Gupta, Clemens, Pivovarsky and Tiongson (2004), which argued not only that aid reduces tax effort, but that the composition of aid matters, with loans, which need to be repaid, encouraging collection, but grants discouraging tax effort. This result is echoed by a more recent study by Benedek, Gupta and Muthoora (2012), which updates the earlier results while expanding data coverage.

However, while these findings of a negative relationship have received significant attention, other recent studies have found that aid has been associated with a negligible, or even positive, effect on levels of tax collection (Gupta 2007, Brun, Chambas and Guerineau 2009, Teera and Hudson 2004), particularly since 1985 (Clist and Morrissey 2011). These cross-country results are echoed by a range of studies that examine the fiscal effects of aid by considering the relationship between aid, domestic revenue (taxes) and government spending (and sometimes borrowing), usually for a specific country. These studies emphasise that understanding the impact of aid on taxation ideally requires information about the whole budget process, including spending, as these studies commonly find that among budget components the tax to GDP ratio varies the least (in technical terms it is exogenous, or not determined by the other variables in the fiscal system; in other words, other budget components make most of the adjustments required to balance spending and revenue). The most important studies in this vein are described in detail in the Appendix. Collectively, these findings cast significant doubt on claims that aid has a consistently negative impact on tax effort, though such an effect may still be relevant in some cases.

These divergent results are in part the result of challenges with the underlying data, as recent studies manage to capture only slightly more than half of potential observations for countries with low incomes and weak institutions. As important as concerns about data quality and sample selection, are concerns about model specification and the interpretation of the findings from 
these studies. Two issues are particularly prominent in this respect: clarifying the underlying behavioural model, and considering multiple causal pathways potentially linking aid and tax collection.

With respect to the behavioural model, Clist and Morrissey (2011) highlight the fact that Gupta et al. (2004) focus on the short-term correlation between aid and reduced tax to GDP ratios. That is, they argue that when grants are high in a given year, tax effort in that same year, or a single year later, tends to be lower. However, this is a potentially problematic model, which is retained by Benedek, Gupta and Muthoora (2012). At a basic level, this finding is to be expected, as the poorest countries, or individual countries in crisis, tend to have lower tax to GDP ratios, and, partly for this reason, tend to receive more aid, particularly in the form of grants. Equally, it implies a behavioural model in which levels of tax collection react very immediately to changes in aid. In practice, changes in tax collection across countries have tended to occur gradually, are often dependent on long-term institutional reform, and, at least in the short-term, have proven challenging even for willing reformers.

A related concern is that the results of cross-country regressions linking aid and tax effort may capture something other than the direct impact of aid on tax effort. One possibility is that aid may impact tax collection indirectly through its impact on, for example, growth, institutions or public financial management (Factora, 2006; Williamson, 2006). Aid to service provision in particular may similarly generate substantial long-term expenditure and revenue commitments for recipient governments, as was acknowledged in the influential World Bank report Accelerated Development in Sub-Saharan Africa (World Bank 1981: 126-128). More perversely, tax effort studies may confuse impact of aid on tax effort with the effect on taxes of policies associated with aid conditionality. For example, trade liberalisation, which has long been a component of aid programmes, has tended to undermine tax collection in low-income countries at least in the short-term by replacing 'easy to collect' trade taxes with 'hard to collect' taxes, such as VAT or income taxes (Aizenman and Jinjarak 2009, Baunsgaard and Keen 2005). In this way, aid conditionality may actually generate a negative association between aid to GDP and tax to GDP ratios in the short run. This helps to explain why some studies find a negative correlation between aid and tax ratios, but it is not due to a behavioural effect of aid reducing tax effort.

\subsection{Aid and tax effort: a more complex relationship}

The argument here is not that aid may not contribute to lower tax effort in some contexts, as such an outcome is intuitively persuasive and supported by some case study evidence (Prichard $2010 \mathrm{~b}$, Ghani and Lockhart 2008). ${ }^{20}$ Instead, the message is that this relationship is far from universal (and, indeed, may frequently be positive), and is significantly more complex than is often suggested. More generally, there are major challenges associated with attempting to capture a simple causal relationship econometrically. Collectively these considerations argue for a more context-specific approach, moving away from asking, 'does aid contribute to lower tax

In Ethiopia, Prichard (2010b) finds that the government was able to sharply reduce tax collection in the aftermath of contested elections in part due to the rapid recovery of aid flows. Ghani and Lockhart (2008), the former of whom served as Minister of Finance in Afghanistan, highlight the lack of attention to revenue-raising by donors in post-conflict Afghanistan, where even the most basic revenue collection functions recovered very slowly in the wake of conflict. More provocatively, Eubank (2010) argues that in Somaliland it was precisely the absence of aid that led the government to focus on tax collection, resulting not only in greater revenue collection but also in constructive 'tax bargaining' that underpinned relatively democratic political processes. Finally, Prichard (2010b) finds that in Kenya a sharp reduction in aid in the early 1990s was an important motivation for implementing an ambitious tax reform programme that led to significant short-term revenue gains, though these gains were partially reversed over time. This finding differs from Morrissey et al. (2007), highlighting the complexity of the relationship, the importance of different time horizons, the very different insights that can emerge from case study and econometric approaches and, most importantly, the need for continuing investigation of these questions. 
collection in developing countries?', and towards asking, 'how do aid flows and associated policy conditions shape tax collection incentives, and under what conditions might this effect be positive or negative?' While this question demands further study, existing evidence suggests a few key insights, which focus on: (a) the need to disaggregate aid into more nuanced categories; (b) the role of institutional quality; (c) the importance of accompanying donor policies; and (d) the broader importance of a context-specific understanding of local incentives.

\subsubsection{What do we mean by foreign aid?}

The basic premise of the argument that aid may reduce domestic tax effort is that aid may act as an effective substitute for domestic tax revenue. However, the extent to which this is true is likely to vary substantially owing to the diversity of interventions captured by the umbrella term 'foreign aid' (Collier 2006). ${ }^{21}$ This is implicit in studies arguing for differential impacts of loans and grants, but the underlying diversity is much more extensive. As such, the first question for donors when assessing the risk of a negative impact of aid on tax effort must be whether or not particular aid flows are, in fact, meaningful substitutes for tax revenue in a particular context.

An important share of foreign aid never goes to the government at all. Aid may be given directly to civil society organisations, may be used to pay for technical assistance or research (in the donor country), or may be directed to parallel implementing structures set up by donors to circumvent recipient governments (this could include much of project aid). While some such aid may, at the margin, deliver services or functions that government is therefore relieved of providing, there is limited reason to expect that aid that does not reach the government will substantially displace domestic tax effort. Unfortunately, available data makes it very difficult to measure the extent of these flows, and thus almost certainly overestimates the level of aid that is genuinely provided to governments. ${ }^{22}$ Morrissey, M'Amanja and Lloyd (2007) indicate the potential magnitude as they found in Kenya that aid to government (as recorded in the budget) rarely exceeded three per cent of GDP, whereas official donor data suggests a figure nearer to ten per cent of GDP on average, suggesting that the data used in existing studies may be misleading.

Even where aid does go to governments, it is frequently allocated for specific projects and purposes. While there is certain to be a degree of fungibility in these cases (e.g. McGillivray and Morrissey, 2000, 2001, 2004; Morrissey, 2006), such aid will rarely be a perfect substitute for domestic tax collection. Direct budget support, which deposits aid funds directly into central government accounts, comes closer to being a direct substitute for domestic revenue. Yet, even here, government freedom is constrained by explicit and implicit conditionality, while the extent of 'effective substitutability' of aid and tax revenue will depend on the details of particular cases. Part of the challenge lies in the fact that more unconditional aid, channelled directly though the government, would seem to pose the greatest threat of discouraging tax collection, but is also highly desirable from the perspective of fostering local ownership and the strengthening of state systems. This is a question that warrants more targeted research, while it also points towards the importance of institutional quality in recipients of relatively unconditional budget support.

\footnotetext{
21 This is a broader problem for econometric work on the impact of aid. For example, the then Chief Economist of the World Bank argued that, 'The empirical literature on aid effectiveness has yielded unclear and ambiguous results. This is not surprising given the heterogeneity of aid motives, the limitations of the tools of analysis and the complex causality chain linking external aid to final outcomes' (Bourguignon and Sundberg 2007: 316). 22 In some respects this measurement problem may be getting worse owing to the proliferation of aid providers (e.g. nonshare of overseas development assistance (ODA) from OECD countries in total aid flows (Severino and Ray 2009).
} 


\subsubsection{The role of institutions}

In developing a more nuanced view of the possible impact of aid on tax effort, research has been most successful in highlighting the importance of institutions. Specifically, limited existing findings are universal in concluding that the relationship is more likely to be negative where institutions are weak. Benedek, Gupta and Muthoora (2012) report that while aid grants always have a negative impact on tax collection, this effect is primarily among states with weak institutions. Brun, Chambas and Guerineau (2009) find that while, on average, aid has a positive impact on levels of tax collection, the impact is negative among states with very weak institutions.

This finding is intuitively persuasive: where institutions are strong, or where reformist governments are in power, they seem likely to view aid revenue as additional resources available for pursuing development objectives, rather than as an excuse to reduce domestic tax collection. Moreover, where institutions are strong, and particularly where the tax administration is strong, tax collection performance is more likely to be stable and insulated from external changes. By contrast, highly corrupt governments may be more likely to take advantage of aid resources in order to avoid tax collection and reform, and the transparency and reduced corruption that are likely to accompany them.

The core message is that the perceived risk that aid may undermine tax collection may be overstated where institutions are strong and reformist governments are in power. This is consistent with a broader aid reform agenda that has argued for transferring greater leadership and ownership to such governments. By contrast, the greatest risk may lie in weak states. This is not to say that direct support to governments may not still be desirable in these cases. Instead, it suggests that in weak institutional environments, and particularly where aid dependence is substantial, donors need to pay greater attention to the risk that aid could undermine short-term tax collection, and thus should potentially adopt strategies to guard against that possibility.

\subsubsection{The importance of complementary donor policies}

The final question, then, is what policy strategies donors might reasonably adopt in those cases, potentially quite limited, where there is a significant risk that aid may undermine local tax effort. At a broad level it is useful to think about interventions along three dimensions: analysis, technical assistance and conditionality.

The first stage for donors must lie in a more careful effort to understand whether or not aid is, in fact, acting as a disincentive to tax collection in a particular context. As was suggested earlier, this is more complex that simply looking at aggregate short-term trends in tax revenue collection. The behavioural variable tax effort is only one element of tax collection. Short-term downward changes in tax collection may reflect reduced tax effort, but may also be driven by, among other things, broader economic trends in the economy, changes in policy, or administrative changes and reorganisation. If short-term changes in tax collection are taken as a direct indicator of tax effort they may be misleading, thus leading to unwarranted conclusions about the impact of aid on tax collection. More generally, the tax to GDP ratio should not be directly equated with tax collection effort; the ratio may appear low simply because the tax base is small and/or the government has chosen, perhaps on the advice of donors, relatively low tax rates to minimise distortions and disincentive effects. 
As importantly, aid is only one of many factors that is likely to shape tax effort. This may equally be driven by domestic politics, including elections, inter-elite conflict or bureaucratic politics. It is necessary to bear in mind that causation is complex: it may be that declining effort is proximately caused by (or, more strictly, due to) domestic political considerations, but facilitated by the availability of donor financing, which makes reduced tax effort economically feasible. For example, a government may reduce tax collection in the lead-up to elections to avoid political resistance, but this decision to reduce tax collection may only be economically feasible thanks to the ready availability of aid. In the absence of aid, the government would not have the luxury of reducing collection (especially as governments often increase spending in the run-up to elections). In these cases, policy action by donors would be appropriate. The broader point is that acting to mitigate any possible negative impact of aid on tax collection first demands some understanding of the sources of variation in tax collection and tax effort, and the consequent openings for donor action.

Confronted with the possibility that aid is undermining tax effort, donors have two major policy levers to fall back on: technical assistance and conditionality. Technical assistance is meant to address capacity deficits, and thus may be able to support improved tax collection where there is a genuine desire for improved performance among domestic actors. Unfortunately, where the problem is one of insufficient tax effort in the presence of large external revenues, such political commitment may not exist, and technical assistance may be limited in its impact. That said, even where there is not universal support for improved performance, carefully targeted technical assistance, which is aimed at supporting genuine reform leaders, may nonetheless help to counteract any lack of tax effort.

The alternative for donors is reliance on tax-related conditionality, by which aid is made conditional on, for example, maintaining a certain level of tax collection, implementing particular types of tax reform or securing matching domestic funds for individual projects. This is, in principle, a direct means of ensuring that government sustains domestic tax collection even in the face of increasing external assistance. However, conditionality confronts at least two major challenges. First, conditionality will only be successful if it is enforceable, which often requires high levels of donor commitment and coordination, both of which are frequently elusive (Koeberle, Bedoya, Silarszky and Verheyen (eds) 2005). Second, conditionality can create incentives for recipient countries to meet very specific targets, but governments may focus on meeting these specific targets rather than investing in building genuinely stronger tax policy and administration over the long-term. Thus, designing conditionality in a way that encourages genuine gains, rather than a complex game of 'cat and mouse' between donors and governments is an important challenge, addressed in the next section.

\section{The growth of conditionality: key questions and messages}

With growing interest in strengthening tax systems in developing countries, and concerns that high levels of aid might erode tax effort in recipient countries, tax-related conditionality has been an important part of donor programmes. ${ }^{23}$ Although monitoring of the use of conditionality is

23 Throughout the discussion, we use the term conditionality in a broad sense to capture the various performance targets 
very limited, it is clear that the use of tax-related conditionality by the IMF has increased in recent years, ${ }^{24}$ while there is anecdotal evidence that this is true of donors more broadly as well (Bolnick and Hadler 2011). ${ }^{25}$ IMF conditionality has been diverse. It has included broad performance targets, focused on levels of revenue collection as well as specific reform objectives, highly binding performance targets, on which continued funding is vitally dependent, and more flexible reform objectives. Such tax-related conditionality is by no means new, as World Bank structural adjustment programmes during the 1980s and 1990s regularly included conditionality related to tariff reductions (e.g. Greenaway and Morrissey, 1993), while the 1980s and 1990s also witnessed significant donor pressure for the introduction of VAT, LTUs and semiautonomous revenue authorities. However, the continued importance, and possible recent growth, of tax-related conditionality makes it an important and relatively under-explored aspect of donor policy.

Indeed, the rationale, design and effectiveness of tax-related conditionality has received minimal attention to date, and, as such, appears to be an area in which donor support could be significantly improved. To this end, the discussion proceeds in three parts. The first highlights a series of major questions about the effectiveness of conditionality generally, and suggests key lessons about what conditionality can and cannot achieve, highlighting some possible alternative strategies. The second section highlights the potential for conditionality generally, and taxrelated conditionality specifically, to generate perverse incentives when it is not carefully designed. The third section then considers the design of tax-related conditionality, and the particular importance of improved, and locally owned, indicators, arguing that reorienting the focus of conditionality is essential to make it more effective.

\subsection{Is tax-related conditionality effective?}

There has been, to our knowledge, no systematic research looking at the impact of tax-related conditionality. A useful starting point is the broader debate about the effectiveness of conditionality, while drawing on specific examples and issues in the tax realm.

At a broad level, conditionality has long been controversial, as it sets up a clear tension between the desire for local ownership of development initiatives, and the desire of donors to insure that aid funds are used effectively (Bolnick and Hadler 2011). Over the past decade, the donor community has increasingly recognised that local ownership of development initiatives is essential in order to foster local political leadership and positive planning and bargaining processes within recipient states. This perspective has supported a preference for aid modalities that are channelled through governments and which rely on relatively parsimonious and resultbased conditionality (e.g. IDD and Associates 2006). ${ }^{26}$ Highly intrusive and detailed

which are established at least in part by donors, and which create pressure for recipient countries to prioritise particular types of objectives over others. Of course, not all conditionality is the same - it may be more or less specific and intrusive, and may be more or less in line with independent government priorities.

24 IMF Presentation at the meeting of the OECD Task Force on Taxation and State Building, USAID, Washington DC, January 2011.

25 Outside of the IMF, requirements for local matching funds for donor projects may be an important indirect source of pressure for increased tax collection, particularly at the sub-national level (Fjeldstad 2001). Unfortunately, there is, to our knowledge, no systematic information on the extent of such practices.

26 It is important to note that the turn towards budget support does not always ensure parsimony in the use of conditions. For example, French budget support in Burkina Faso is delivered as part of a multi-donor framework, which comprises a fixed component $(2 / 3)$ and a variable component $(1 / 3)$. French disbursement of the variable component is conditioned in part by tax collection performance, but the overall range of conditions employed by donors generates a matrix with 100 total criteria, making the effectiveness of even this simple revenue condition open to question. While there has been discussion of moving to a smaller number of outcome criteria, this would likely result in tax-related conditionality being eliminated entirely. 
conditionality is contrary to that goal, and risks undermining local planning processes that provide the essential basis for sustainable gains.

On the other hand, conditionality is one of the few tools available to donors to generate pressure for desirable reform, and to seek to minimise any risk that aid might undermine tax effort, particularly in weak institutional reform. Moreover, at times conditionality can be used to buttress the political positions of prospective reformers in the face of resistance. The potential costs associated with undermining local ownership thus suggest a need to use conditionality selectively and carefully, but do not necessarily rule out the effectiveness of well-designed conditionality.

This turns attention towards the more specific question of whether conditionality is effective in achieving its stated goals. Despite the absence of systematic research, there is certainly anecdotal and some cross-country evidence that in a wide range of countries pressure from donors has helped to advance tax reform efforts (Prichard 2010b, van Soest 2007a, 2007b). ${ }^{27}$ Broadly, the dramatic convergence of developing country tax policies over time is suggestive of some success for conditionality (Sanchez 2006). More specifically, Mahon (2004) finds that tax reform programmes are more common, and more frequently successful in changing tax policy, in countries that have signed agreements with the IMF. Brun, Chambas and Laporte (2010) find that participation in an IMF programme leads to increased tax collection, consistent with the view that conditionality (and technical assistance) plays an important role, though this positive impact of IMF programmes is stronger where the quality of public administration is higher.

While there is thus some evidence of a positive impact of conditionality, the more interesting message is that the effectiveness of conditionality is heavily dependent on the level of domestic support for reform. Morrissey (1995) finds that donor conditionality and technical assistance are most successful when they go hand-in-hand with the construction of domestic political support for reform. More generally, conditionality appears to be more successful where it effectively supports the efforts and strategies of local reform leaders, rather than imposing purely external priorities - a notion consistent with increasingly accepted ideas about the importance of 'going with the grain' in pursuit of 'good enough' solutions (Crook and Booth 2011, Grindle 2007). This said, even where local reform leadership is limited, it does appear that conditionality has, at least in some cases, been able to promote formal changes in policy and administration. However, in these cases reform more often appears to have been superficial, and the question is then whether even superficial changes in the short term may nonetheless contribute to longer term gains; or may do the opposite, either by undermining local ownership or, as discussed later, generating unintended perverse incentives.

If a lack of local ownership and leadership is thus one key variable in shaping the effectiveness of conditionality, existing research suggests three other issues that are more firmly under the control of donors: monitoring, coordination and resolve (Collier, Guillaumont, Guillaumont and Gunning 1997, Svensson 2003, Koeberle, Bedoya, Silarszky and Verheyen (eds) 2005, Easterly 2005). It is only with greater attention to these issues that conditionality is likely to be fully effective. $^{28}$

$27 \quad$ For example, Ethiopia undertook significant tax reform that was initiated in the late 1990s but only implemented in earnest from 2000-01. Tax officials there are in near universal agreement that, at a time of significant in-fighting within the government, it was consistent external pressure that was central to keeping tax reform efforts moving forward. While the extent of the changes should not be overstated, meaningful policy change, administrative reform and increased revenue collection were all apparent. Similarly, in Ghana after a first effort to introduce VAT in 1995 was reversed in the face of major public opposition, donor support figured prominently in supporting the efforts of reform leaders to successfully reintroduce the controversial tax in 1997 (Prichard 2010a).

28 For example, repeated donor projects in Bangladesh since 2003 accomplished few, if any, of their goals, despite the 
Conditionality will only be effective if desired outcomes can be effectively monitored, and, as a result, conditionality may frequently lead to the superficial appearance of reform, while little change is enacted in practice. This appears significant in the case of tax-related conditionality, where, as noted earlier, formal changes in tax policy and administrative structure have frequently failed to deliver equally significant changes in actual administrative practice, ${ }^{29}$ or have been implemented, but then partially reversed as donor involvement declines. The message is that conditionality, when employed, must hold the potential for meaningful monitoring; a task made much easier where there is significant local support for reform.

Even assuming that conditionality can be monitored, effectiveness demands that donors be coordinated in their demands, and have the resolve to withhold aid if conditions are not implemented to some pre-established extent. In practice, these requirements are frequently not met (van de Walle 2005, Frot and Santiso 2010). In many cases donors set different conditions or performance targets, thus complicating their ability to create significant pressure for reform in recipient countries (quite aside from the transaction costs created by such fragmentation). Even when performance targets are shared, there may be disagreement about the type of response that is justified when conditions or targets are not met, given the complexity involved in evaluating the causes of underperformance. ${ }^{30}$ Finally, in some cases donors may differ in their underlying willingness to reduce funding levels in order to enforce conditionality. At its simplest, this may reflect broad pressure to disburse funding and reluctance among donors to produce negative assessments of funded programmes. Deeper problems may emerge where donors have specific economic or geo-strategic interests in recipient countries that make them unwilling to take a hard stance in the face of an unwillingness to pursue reform (Dunning 2004, Moss, Roodman and Standley 2005, Montinola 2010).

The message is thus not that conditionality cannot be an effective policy lever, but that its effectiveness is likely to be context-specific, and dependent on careful design and implementation.

\subsection{Designing conditionality and the importance of better indicators}

Even if conditionality is effective in providing an incentive to governments to adopt particular reform, this will only be of net benefit if those conditions are, in fact, consistent with the long-term goal of building a stronger tax system. On the surface this statement is straightforward, but, in practice, there are a variety of ways in which conditionality may fail to target desirable reform or, worse, may inadvertently create perverse incentives and outcomes. As such, careful design, supported by the development of more appropriate indicators, is essential.

The most basic risk is that the stipulation of unrealistic and unattainable targets may lead to poor planning and the unfair withholding of aid from recipients. Thus, for example, if donors push for unrealistic tax collection goals, this may result in unfairly penalising recipient governments when targets are not met. Similarly, unrealistic revenue projects may lead to corresponding demand

\footnotetext{
eventual attachment of tax reform-related conditionality to the IMF country programme. At the centre of this conditionality was a demand that Bangladesh introduce a reformed Value Added Tax, but after extended preparation of the new law, several IMF missions and pledges of support from various other donors, the government announced shortly before the presentation of the 2012 budget that it would not, in fact, be presenting the new law to parliament.

$29 \quad$ An early study of the political economy of tax reform proposed that seemingly controversial tax policy changes have sometimes been accepted by elites precisely because of confidence that implementation would be weak (Ascher 1989: 443).

30 As is discussed below, one cause of disagreement in enforcing targets is the fact that the targets themselves are often somewhat arbitrary, thus opening the door to disagreement over whether poor performance against targets reflects government failure, or other issues.
} 
for increased public spending that cannot, in fact, be financed. This is not a hypothetical concern; there are cases, for example, where the IMF has set revenue targets as part of stabilisation programmes that have proved unattainable. Finally, and less obviously, unrealistic targets may, perversely, lead recipient countries to adopt short-term measures to meet those targets even where they are inconsistent with longer term or broader development goals.

This last issue points to the broader concern that even if goals are realistic in a narrow sense they may nonetheless generate unforeseen, and potentially perverse, incentives and outcomes. Fjeldstad (2001) recounts the case of revenue conditionality in rural Tanzania, which led to increased levels of tax collection but also encouraged the use of increasingly coercive methods of tax collection. While poorly documented, this perverse tendency of crude revenue targets to foster a 'focus on targets' rather than a focus on building stronger tax systems over the long term appears, anecdotally, to be a broader concern. ${ }^{31}$ Not only are highly coercive practices designed solely to meet targets inherently undesirable, but they also distract attention from longer term goals and may undermine public support for the tax system, and thus undermine more valuable long-term reform efforts. ${ }^{32}$ Needless to say, when revenue targets are set at unrealistic levels this holds the potential to further exacerbate such perverse incentives.

While poorly researched, it is straightforward to imagine other ways in which meeting specific, narrow, targets may also have unintended costs or even undermine longer-term reform. For example, conditionality and performance targets that emphasise some areas of tax policy or administration risk strengthening those areas at the expense of others. For example, tax administrators frequently express concerns that the creation of Large Taxpayers' Units may distract attention from other areas of tax administration. There is similarly anecdotal evidence that the introduction of VAT may draw resources away from other areas of tax administration. ${ }^{33}$ Such reallocation of resources is not inherently problematic, but is a reminder that conditionality often generates incentives to meet specific goals, whether or not they are consistent with the broader long-term goal of strengthening the tax system.

The obvious response to such concerns is to design better conditionality, based on better performance targets, thus ensuring that conditions are set in a way that is consistent with achieving both short- and long-term improvements. Donors as a group have traditionally relied overwhelmingly on the tax share of GDP as the most important indicator of performance, with all of the potential risks noted above. The alternative has tended to be conditionality based on a set of highly visible policy and administrative reforms, as discussed previously. However, these priorities, while perhaps justified, leave largely unaddressed the 'softer elements' of tax administration, which are essential to building taxpayer trust and expanding voluntary compliance (Bird 2008, Bird and Vazquez-Caro 2011). Tax experts increasingly emphasise the fact that tax modernisation is not simply about changes in policy and administration, but also about reorienting broader norms (Aberbach and Christensen 2007). Bird and Vazquez-Caro (2011) specifically argue for a move from an adversarial compliance model towards a cooperative (or collaborative) model, backed by a focus on equity above maximisation of revenue collection, reduction of transaction costs, greater transparency, use of information technology (IT) and the careful development and management of human resources. It is these factors that

$31 \quad$ This is equally an issue in relation to a sometimes excessive focus on revenue targets within domestic tax agencies, where taxpayers and tax officials alike frequently attribute particularly coercive tax practices to the 'need to meet their targets'. This is an inherently difficult claim to study empirically, but this view is widely shared by tax officials and reformers. Indirect support for the claim comes from evidence that the behaviour of tax officials towards taxpayers can significantly reduce reported support for government and tax compliance (Fjeldstad 2004, Berenson 2006).

For example, in Sierra Leone many senior staff were transferred directly from the Direct Tax Department of the National Revenue Authority to the newly created VAT Department, and staff regularly argue that there was a clear trade-off in government policy, driven by donor demands (Prichard and Jibao 2010). 
need to be borne increasingly in mind in the design of tax reform programmes, and related conditionality and performance targets.

Achieving this goal depends on both an attitudinal shift among donors and providers of technical assistance, and the development of clearer, more nuanced and more appropriate indicators of tax system performance (Bolnick and Hadler 2011). Positive steps in this regard are apparent in growing attention to developing such indicators, including a major initiative currently being piloted by the World Bank (World Bank 2012). These efforts should be applauded but challenges remain. First, with growing interest in such benchmarking exercises there is a need to ensure that donors work co-operatively, as there is otherwise a risk of the proliferation of contrasting benchmarks. Second, there is a need to ensure that these new benchmarks are actually put into practice, not only on paper, but also in the attitudes and priorities of those involved in reform programmes. The need for more careful, and context-specific, benchmarking has long been acknowledged among donors, but progress has been very slow (Barbone, Das-Gupta, de Wulf and Hansson 1999, de Wulf 2000, Gill 2000, IEG 2008). ${ }^{34}$ Third, and perhaps most acutely, there is a need to ensure that these new indicators do not devolve into an endless checklist of requirements largely disconnected from particular contexts and needs. The motivation for developing new indicators is precisely the need to ensure that conditionality addresses local needs, is embedded within a broader reform plan and does not create perverse incentives to simply 'meet targets' even at the expense of actual reform objectives. However, the risk of falling into such reductionism is significant.

Related to this risk is the need to ensure that benchmarking exercises are conducted in partnership with local leaders. As Bird and Vazquez-Caro (2011: 3) explain:

An additional problem with some benchmarking of tax administrations, especially in developing countries, is that many such exercises have been carried out more by outsiders, such as those who pay (donor agencies) or those who criticise (Non-Government Organisations (NGOs)), than by tax administrations themselves. If those who must generate most of the critical data needed for a benchmarking exercise are aware that they will be judged by it and they see no direct benefits for themselves from accurate reporting, accurate reporting is unlikely to ensue. ${ }^{35}$

Thus, if benchmarking and the related conditionality are to be fully effective, the goal should be to develop specific benchmarks and targets in partnership with local tax administrations, informed by general principles about good tax practice that go beyond simply maximising taxpayer revenue. ${ }^{36}$

This said, it is useful to conclude by returning to the potential tension between fostering local ownership and developing relatively sophisticated and detailed conditionality. There is a strong argument for keeping conditionality to a minimum where possible, and for budget, rather than

$34 \quad$ For example, Barbone et al. (1999: ii) wrote of 'the need for a standard diagnostic tool, a greater focus on and integration of governance components in project design, the development and use of a standard set of administration performance indicators and also a standard appraisal methodology'.

35 Though not specific to developing countries, similar sentiments can be found in Behn (2003), while Crandall (2010) cites the example of Romania, where performance management targets fell into disuse because they were not viewed as relevant by senior officials.

36 They go somewhat further and argue for a shift away from reliance on quantitative and qualitative benchmarks and towards what they call 'systemic benchmarking' which seeks to benchmark performance around sets of activities related to specific administrative priorities. This is, in their view, a way of ensuring that benchmarks are genuinely useful for informing reform strategies, rather than acting as simple 'grading' exercises. This is undoubtedly good advice, though is likely to be a longer-term goal in most low-income countries and is thus not fully developed here. 
sector-specific, support. However, particularly in weak institutional environments, this risks either placing insufficient emphasis on revenue raising or implicitly promoting a reductionist approach to reform, centred exclusively on increasing the tax share of GDP. Adopting more detailed conditionality, or more targeted support to the tax administration, are a means to address these risks, and promote a more complete vision of reform, but, unless handled carefully, may do so at the expense of fostering local ownership (Bolnick and Hadler 2011).

\subsection{Alternative forms of conditionality}

The message of the preceding discussion is that conditionality can have a role to play in supporting reform, and, where necessary, in managing the risk that aid may undermine tax effort. However, for this to be effective, and avoid creating perverse incentives, there is a need for very careful thought about rationale, design and implementation. This means: (a) seeking to design conditionality that supports local initiatives and reform leaders, rather than simply driving an external agenda; (b) ensuring careful co-operation and co-ordination among different donors; and (c) employing more nuanced indicators, developed in partnership with local reform leaders.

Given the complexity of these needs, it is equally likely that in some circumstances reliance on traditional forms of conditionality may simply not be appropriate or effective, despite the best intentions. Most obviously, where governments are sufficiently resistant to reform, the risk that conditionality will fail to secure more than superficial reform and that donor resources will be squandered is significant. In such settings reliance on either greater selectivity, or 'cash on delivery' modalities, may be more appropriate.

Selectivity may occur at both macro and micro levels. At a macro level, it implies delivering aid only where governments have already shown a commitment to reform, as with the US Millennium Challenge Corporation (Rieffel and Fox 2008). This, though, has the disadvantage of ruling out aid to many of the cases most in need of reform. At a micro level, selectivity implies focusing on reform objectives that are relatively 'incentive compatible' with existing political priorities, thus advancing limited reform even in contexts in which broader reform may be impossible (Hassan and Prichard 2012). Such incremental reform in difficult environments may be very valuable, but demands that donors be patient and invest in relatively detailed political economy analysis. This approach is consistent with conditionality as 'monitoring and dialogue' rather than as promoting specific reforms (Morrissey 2005).

An alternative, and related, possibility is raised by Bolnick and Hadler (2011), who propose the potential value of a 'Cash on Delivery' (COD) approach (Birdsall and Savedoff 2011). ${ }^{37}$ This would imply negotiating clear and verifiable performance criteria with government, and stipulating aid payments from donors if and when those performance criteria are achieved. Such a modality may be particularly valuable in contexts in which local political leadership has been clearly absent, and donor projects have repeatedly failed to meet objectives as a result. In such contexts, a COD approach would place the onus on government to tangibly demonstrate political leadership before receiving any donor support. That said, such an approach is far from a magicbullet for reform: it does not alleviate the risk of reform reversals, relies critically on the identification of effective targets, potentially places priority-setting in the hands of donors rather than government, and may reduce the scope for proactively supporting potential reform leaders. Moreover, given that outcomes are shaped by many factors, some of which are not under the control of government, this modality may fail to recognise committed reform efforts that

37 The World Bank has recently introduced such an aid modality, which it terms 'Program for Results'. 
nonetheless fail to achieve desired outcomes (Morrissey 2005). This is especially important for targets related to tax revenue.

\section{Beyond tax reform: additional issues for donors}

The discussion so far has focused on the ways in which donors can directly contribute to strengthening tax systems in the developing world. However, the success of developing country tax systems is equally shaped by the external policy environment. We conclude with a discussion of three ways in which broader donor actions could improve the overall environment in which tax reform programmes are undertaken, and thus contribute significantly to improved outcomes.

\subsection{Donor proliferation}

One consequence of surging donor interest in tax issues is the risk of a proliferation of poorly coordinated donor initiatives aimed at tax systems in developing countries. Donor assistance on tax has historically been dominated by the IMF, the World Bank and a small group of bilateral donors, led by DfID (UK) and GTZ (Germany, and recently renamed GIZ). This picture appears to be changing, though measuring potential proliferation concretely is very difficult. The potential costs of a lack of donor coordination are well-known, including: (a) high transaction costs and administrative fragmentation in recipient countries; (b) poorly coordinated, or even contradictory, reform objectives; (c) instability of reform goals and related funding; and (d) difficulties in effective monitoring and evaluation (e.g. Morss, 1984, Acharya, de Lima and Moore 2006, Roodman 2006, Djankov, Montalvo and Reynal-Querol 2009). The need for effective donor coordination is central to the Paris Agenda for aid reform, but progress in practice has been slow (OECD 2009). While coordination problems are most acute in areas of service delivery, growing donor interest in tax issues suggests that this is an area in which questions of coordination may demand increasing attention.

\subsection{The tax treatment of aid-funded goods and services}

Despite significant attention to the issue in recent years, many aid-funded goods and services continue to benefit from significant tax exemptions, which may undermine the quality of tax systems in recipient countries (Boyce and O'Donnell 2007a, 2007b, Boyce and Forman 2010, Carnahan 2007). The logic of these exemptions is clear-cut: aid funds are generally designated for particular projects and purposes, and the taxation of those funds amounts to a reduction in development-oriented spending in those areas. While tax revenues still accrue to the government, there is no guarantee that they will be used for the agreed purposes - in effect, tax revenue from aid projects amounts to unconditional donor support to the national budget. However these arguments ignore both the reality that donors already deliver significant funding directly to many developing country budgets, and the significant negative impact of exemptions on tax administration and tax norms.

With respect to delivering aid directly to government budgets, many donors have already moved to providing a larger share of aid through direct budget support. It is in these cases that tax exemptions for aid-funded goods and services could be removed without meaningfully increasing the risk to donors, as the provision of direct budget support already reflects an 
expression of confidence in local budgeting, financial management and priority setting (Morrissey 2006). Doing so could, in fact, amount to little more than an accounting exercise: project funding could be increased in proportion to expected tax liabilities, and direct budget support reduced by an equivalent amount, on the assumption that the same revenue will reach the budget through the tax system. Such a reform would also deliver tax efficiency gains, as it is not the aid that is taxed but the goods, typically imports, purchased with the aid, which are taxed at prevailing tax rates. Where tax rates are low (e.g. most capital goods) or zero (e.g. medicines or textbooks), taxes will remain negligible, while only luxury goods (e.g. vehicles) would be taxed heavily.

The justification for such a change lies in the fact that existing exemptions impose substantial costs on developing countries, and represent an apparent case of donor hypocrisy. While little specific research has been done, it is clear that the scope of such exemptions is large: in Sierra Leone, relief from customs duties alone amounted to roughly 10 per cent of total government revenue, and 1 per cent of GDP. Administratively, it is costly to administer exemptions, and the proliferation of exemptions can open the door to abuse, as exemptions are illegally claimed for ineligible activities. ${ }^{38}$ Equally important is that widespread tax exemptions may undermine the norm of tax compliance within society as a whole. Those involved with aid projects are frequently very wealthy by local standards, receiving high salaries, living in large homes and driving expensive cars. Regardless of the officially charitable intent of the work, local taxpayers are virtually certain to ask why they should bear a large tax burden when much wealthier individuals are excused from significant taxation. More generally, at a time when donors are increasingly demanding that developing country tax administrations increase transparency and curb tax incentive regimes, their own unwillingness to reform sets a highly contradictory example.

\subsection{Donors, tax havens and international tax evasion}

It is increasingly apparent that an important barrier to improved tax performance in the developing world is the ability of elite individuals and multinational companies, including natural resource firms, to make use of off-shore financial centres (OFCs), more commonly known as 'tax havens' or 'secrecy jurisdictions' to engage in tax evasion. While it is difficult to precisely estimate the impact of these practices on tax collection due to the secrecy involved, recent studies suggest that the lost tax revenue may be very substantial (Baker 2006, GFI 2008, 2010). Recent data being compiled by the Tax Justice Network and Christian Aid, for example, suggests that revenue losses from only a single method, transfer mispricing, may be as high as 5 to10 per cent of total tax revenue in many low-income countries (Prichard 2009, Cobham 2005). Even if actual levels are significantly less than these estimates, they nonetheless represent a significant share of total tax revenue.

The implications of these forms of tax evasion are threefold. First, they seriously undermine overall levels of tax collection in the developing world. Second, they are likely to contribute significantly to tax system inequality, as it is wealthy individuals and large firms that are able to exploit tax havens for financial benefit. This is not only objectionable on normative grounds, but uneven enforcement has been widely shown to undermine voluntary tax compliance among other taxpayers (Berenson 2006, Fjeldstad 2004). Further, by fragmenting taxpayers' interests, such inequity may well also undermine the potential for taxation to lead to explicit and implicit tax bargaining as taxpayers seek broader responsiveness and accountability (OECD 2010, Prichard 2010a). Third, ready access to the anonymity provided by tax havens may also facilitate

38 While estimates of such abuse are obviously problematic, it is interesting to note that a survey of taxpayers in Tanzania found that religious and charitable organisations were viewed as a major source of tax evasion, while similar views appear to be common across the developing world (Gray 2001). 
corruption of various kinds including, for example, bribes paid in order to secure favourable tax treatment, particularly by firms in extractive industries (Palan, Murphy and Chavagneux 2010).

While international organisations have recognised the negative implications of tax havens at least since the 1998 OECD report on Harmful Tax Competition, recent years have seen growing recognition of the negative implications of tax havens specifically as an issue for developing countries. This has, in turn, spurred growing appreciation that donor agencies should be among the most vocal advocates of measures to curb such abuse. ${ }^{39}$ Unfortunately, devising an appropriate response is a more complex challenge, as even the most sophisticated tax administrations in developed countries struggle to control such tax evasion (Keen forthcoming).

Two tracks have dominated discussion and activity, but there are major questions about the efficacy of both sets of measures. The first set of activities has focused on providing expanded technical assistance to developing countries to deal with tax evasion by multinational firms in particular. A significant part of this effort has focused specifically on firms in extractive industries, where concerns about both tax evasion and corruption are particularly acute. ${ }^{40}$ However, while this is welcome, there is a need to be realistic about the likely scope for progress, as the technical capacity required to significantly curb such tax evasion may be largely beyond the reach of many low-income countries in the short to medium term, even with significant capacitybuilding support. In addition, there is a need for very careful co-ordination of donor support in order to ensure that targeted support for dealing with evasion by multinationals is well integrated with broader tax reform programmes and priorities.

The second reform track has placed emphasis on improving the exchange of information between tax administrations in different countries in order to facilitate improved enforcement (TJN 2009). However, while the principle of transparency is laudable, many contend that even if developing countries are able to sign exchange of information agreements with relevant tax havens, the burden of proof required in order to access and exploit external information may likewise be beyond the reach of many countries (TJN 2009, Murphy 2009). This technical barrier is compounded by the fact that political resistance by elites may seriously undermine such efforts, much as political resistance has ensured the continued weakness of income taxes across the developing world (Bird and Zolt 2005). There is thus real concern that these measures may create the appearance of action without any serious likelihood of success. ${ }^{41}$

Confronted with this reality, there is a strong case for donor agencies to become more vocal advocates for more ambitious reform measures. One such proposal has been to replace international exchange of information agreements with automatic exchange of information, with information on all taxpayers being sent automatically to countries of residence (TJN 2009, Murphy 2009). However, this measure has been criticised in many quarters on the basis that developing country administrations may be overwhelmed by information. An alternative proposal has been for changes in international corporate accounting standards to require country-bycountry reporting by multinational firms. This would require that all companies report revenue, profits, tax payments and other key financial data on a country-by-country basis, thus dramatically simplifying the task of detecting international profit shifting and tax evasion (Christian Aid 2010, TJN 2008). ${ }^{42}$ This proposal has found wide-ranging support from

\footnotetext{
39 There are a wide array of forums and organizations involved in these processes, among them the OECD Tax and Development Task Force, the International Tax Compact and recent commitments by the British and Norwegian development agencies to support significant research in this area. The Extractive Industries Transparency Initiative has similar goals, though relying more heavily on civil society engagement and pressure (e.g. Haufler 2010). Keen (forthcoming) raises this question, though not as explicitly or in precisely these terms. See, for example, <http://www.financialtaskforce.org/issues/country-by-country-reporting/>
} 
researchers, activists and some members of governments, but has faced stiff resistance from multinational firms.

Over the longer term there remains a simple need to put pressure on tax havens themselves to become more transparent and to desist from predatory practices designed solely or primarily to facilitate tax evasion or other forms of illicit activity. There is a precedent for this, in the creation of an OECD 'black list' for non-compliant jurisdictions, but the standard of transparency is currently comparatively low. Regardless of specific goals, donor agencies should be prominently involved in continuing to push these concerns to the forefront of international discussions, as the challenges facing developing country tax systems cannot be seen in isolation from the broader international policy environment. Doing so would mean development agencies increasingly engaging with Ministries of Finance within their own countries, as it is decisions by these ministries that are particularly central to shaping the international policy context.

\section{Conclusions}

Collectively, the messages in this paper amount to a significant challenge to donors as they seek to strengthen their efforts to support developing country tax systems. Of course, the issues covered here are neither exhaustive nor entirely new. Instead, this paper is an effort to focus attention on a series of 'big picture' issues that have often been noted, but which have been inadequately analysed and too infrequently integrated into policy on the ground. The goal is to support donors in building on the meaningful successes of the past by deepening the impact of reform efforts and broadening the agenda to encompass a larger range of governance concerns and greater attention to the international policy context for reform.

As important as the individual messages raised here is the extent to which they are interconnected, and thus represent an overlapping and relatively coherent agenda for strengthening donor engagement. At a domestic level, complementing the existing agenda with greater attention to the 'soft' elements of tax reform - including equity, transparency, inclusiveness and a focus on taxpayer services - holds the potential both to help to address political barriers to reform and to strengthen links between taxation, state-building and governance. This domestic agenda needs to be complemented by an international agenda that addresses more systemic barriers to effective tax systems in developing countries. This includes a more nuanced understanding of the impact of aid, both positive and negative, on domestic tax effort in particular contexts, efforts to reform tax exemptions for aid-funded goods and services, and more proactive donor involvement in addressing the impact of tax havens on developing countries.

Underpinning these specific issues is the need for broader improvements in donor processes. This must begin with thinking more carefully about the nature of donor conditionality and benchmarking. Moving the focus of tax reform efforts beyond the tax share of GDP is important to achieving more meaningful and lasting reform, and to incorporating governance considerations into the reform agenda. However, the use of conditionality must include an understanding of the local political economy, and the consequent potential for conditionality to support reform in particular contexts, and must be carefully balanced with a concern for strengthening local reform leadership. Finally, the success of all of these reforms depends on effective coordination among donors, a commitment to fostering local ownership of reform and a 
willingness to incorporate political economy analysis into the design of interventions that are tailored to local needs, and thus embrace a degree of heterodoxy, patience and selectivity. 


\section{Appendix}

\section{Existing evidence linking aid and tax effort}

Over slightly more than a decade, there has been a wide range of studies seeking to explore the impact of aid on tax effort in recipient countries. This appendix provides a detailed review of those findings and key technical disagreements within the literature.

Most of the early results in this literature reported that aid discourages tax collection across countries (Mahdavi 2008, Remmer 2004, Gupta, Clemens, Pivovarsky and Tiongson 2004, Devarajan, Rajkumar and Swaroop 1999, Bräutigam and Knack 2004, Knack 2009). The most influential of these results was that of Gupta et al. (2004) from the IMF, which not only found that aid reduces tax effort across countries, but also argues that that the composition of aid matters. Loans, which need to be repaid, encourage collection, but grants discourage tax effort. Responding to subsequent challenges to these initial findings, Benedek, Gupta and Muthoora (2012) replicated and expanded the initial study using a more up-to-date and complete data set, covering the years 1980 to 2009 . The new study further explored the robustness of the sample to selection bias, finding that the results are robust across samples, though the negative impact of aid on tax effort is larger in weak institutional environments.

However, the study is not without limitations: the new data set employed by this more recent study, while a step forward, still only covers 2,465 of a possible 3,510 observations within their entire sample (70 per cent), and 999 of a possible 1,710 observations among countries with weak institutions (58 per cent). ${ }^{43}$ This data problem is common to all existing studies and, coupled with broader concerns about data accuracy and the inconsistent treatment of resource revenues, suggests that results should be treated with caution.

Aside from this basic concern about data quality, a variety of studies have challenged the finding of a negative impact of aid on tax effort, raising questions about both the robustness of the results and model specification. Among recent studies, Gupta (2007) and Teera and Hudson (2004) report a negligible impact of aid on total government revenue, Clist and Morrissey (2011) report no robust negative relationship, and a possible positive impact of aid on taxation since 1985. Brun, Chambas and Guerineau (2009) report that the impact of aid on tax effort is contingent on institutions, with a negative impact in weak institutional environments, but a positive effect in developing countries with stronger institutions. These divergent results reflect differences in data and specification and, collectively, cast major doubt on the robustness of claims about a consistently negative impact of aid on tax effort.

The most thorough peer-reviewed response to Gupta et al. (2004) comes from Clist and Morrissey (2011), who address the effect of aid loans and grants on tax effort using data for 82 developing countries over 1970-2005 and find no robust evidence for a negative effect of aid grants on the tax to GDP ratio. While they do replicate the Gupta et al. (2004) results, they argue

The missing data is almost certainly non-random and concentrated in resource dependent states, states involved in conflict and those with poor relationships with the International Financial Institutions (IFIs). The problem of missing data is exacerbated by the widely accepted fact that there are significant inaccuracies in the existing databases, while the treatment of resource revenues is highly inconsistent, leading to a further risk of misleading results (Cobham and Goodall 2011, Prichard 2010b). These problems are common to a greater or lesser degree in all existing studies, and the case for treating these results with caution is thus compelling. 
that these are due to a mis-specification of the relationship of interest. Specifically, they argue that Gupta et al. (2004) identify a contemporaneous correlation between aid and reduced tax collection - higher aid, especially grants, is associated with lower tax to GDP ratios; but that this is to be expected, as the poorest countries tend to have lower tax to GDP ratios and, partly for this reason, tend to receive more aid, particularly in the form of grants.

By contrast, they argue that the prediction that aid reduces tax effort implies a behavioural relationship, which can only occur over time. As such, they argue that it is necessary to introduce lagged effects of aid on taxation, and they find that allowing for even moderate lags on aid (five years in a panel context) eliminates the negative aid effect. Clist and Morrissey (2011) use longer lags on the assumption that the impact of aid on tax effort is more likely to occur over the medium term (discussed further below). Intuitively, the argument for longer lags reflects the fact that sustained changes in tax collection are likely to occur only over the medium-term making the search for immediate tax responses to changes in aid potentially misleading. They suggest that this is particularly an issue in low-income countries, where low revenue is likely to encourage high levels of aid, while sustained improvements in revenue performance have been frequently difficult to achieve, with collection outcomes shaped by deep-seated historical factors (Keen and Simone 2004, Teera and Hudson 2004, Mkandawire 2010). The message is not necessarily that a particular lag length is 'right' but, rather, that the causal pathway from higher aid to changes in tax collection is highly complex, and potentially highly variable, and thus raises important challenges of model specification, particularly when looking at cross-country data.

As importantly, Clist and Morrissey (2011) highlight the need to consider the multiple pathways through which aid may shape tax outcomes, and thus to carefully assess what conclusion can be drawn from existing results. Studies of aid and tax effort are focused on the behavioural impact of aid on taxation: that is, the possibility that aid may reduce efficiency (effort) in the collection of tax revenue. However, it seems at least equally likely that it is policies associated with aid (conditionality and technical assistance) that have effects on tax revenue (on rates, bases or collection). The controls that are generally included in tax effort studies to proxy for the tax base (such as agriculture and industry shares in the economy, GDP, imports and exports) cannot adequately account for these policy effects. In simpler terms, aid is likely to shape tax performance through multiple channels (behavioural effects, conditionality/policy and technical assistance) and these effects may move in different directions, and may be difficult to distinguish from each other.

They argue that the tax effects of policy reforms are potentially very significant, but are difficult to identify with confidence. For example, they find that in the past 15 to 20 years low-income aid recipients have managed to increase tax ratios, and suggest that this may indicate that in many aid recipients the policies associated with aid may have supported increasing tax to GDP ratios. This may not only reflect the influence of policies targeting tax performance, as aid projects that shape broader outcomes, such as growth or institutional quality, may equally influence tax collection. Illustrative of the importance of considering the tax effects of aid policy, Clist and Morrissey suggest ways in which simple correlations in the data may not reflect any causation. For example, some policies associated with aid tend to reduce tax revenue: economic liberalisation has typically been a component of conditional lending (aid increases), and such reform episodes are generally associated with tax revenue reductions. Aizenman and Jinjarak (2009) show that reforms such as trade liberalisation erode the revenue from 'easy to collect' taxes such as tariffs (which tend to be most important for poorer countries). Poor countries have difficulty replacing the lost revenue through 'hard to collect' taxes, such as VAT or income taxes. Thus, periods of economic policy reform in developing countries tend to be associated with reductions in the tax to GDP ratio, especially for the poorest countries (Baunsgaard and Keen 
2005), but they also tend to be associated with aid episodes. In this way, aid conditionality may actually generate a negative association between aid to GDP and tax to GDP ratios in the shortrun. This helps to explain why some studies find a negative correlation between aid and tax ratios, but it is not due to a behavioural effect of aid reducing tax effort.

Alongside these cross-country regression studies, important evidence emerges from studies that examine the fiscal effects of aid by considering the relationship between aid, domestic revenue (taxes) and government spending (and sometimes borrowing), usually for a specific country. This approach has the advantage of looking in detail at changes in aid and taxation within countries, while it highlights that one cannot reliably draw inferences about the effect of aid on tax revenue from observations of the value of aid and the tax to GDP ratio alone. Aid and tax revenue are only two components of the financing side of the budget (borrowing and non-tax revenue are the others); to understand how financing components affect each other one needs to consider the whole budget process, including spending. A common finding in these studies is that the tax to GDP varies the least (in technical terms it is exogenous, or not determined by the other variables in the fiscal system; in other words other budget components make most of the adjustments required to balance spending and revenue).

Lloyd, McGillivray, Morrissey and Opoku-Afari (2009) apply a common country-specific fiscal response analysis to a sample of 19 countries. The main finding is that aid is a significant element of the fiscal relationship for a variety of developing countries (including a number of middle-income countries for which aid is a relatively small share of spending. That is, they confirm that aid does influence budgetary behaviour. For the majority of countries aid is weakly exogenous (i.e. donors do not respond to fiscal imbalances in determining their allocation, but aid has effects on the other fiscal variables), and is positively associated with spending (both capital and recurrent). The relationship between aid and tax revenue varies: negative in seven cases, positive in five cases, and insignificant in the other seven. Moreover, the negative relationship is typically because aid declines as tax revenue increases (i.e. over time donors reduce aid alongside increases in tax revenue). This appears as a negative correlation between aid and taxation, but does not imply that aid is causing reduced tax effort. Ouattara (2006) echoes this finding for the case of Senegal.

A few recent studies extend the time series econometric methods to estimate the relationships between aid and fiscal aggregates (revenue, spending and borrowing). Osei, Morrissey and Lloyd (2005) show that aid to Ghana from the 1980s was associated with reduced domestic borrowing (because reducing domestic borrowing was a requirement imposed by the IMF), and increased tax revenue (because of reforms in the cocoa sector promoted by the World Bank). Morrissey, M'Amanja and Lloyd (2007) find that aid had no impact on tax revenue in Kenya, as tax collection has been very stable over time despite short-term fluctuations. Martins (2010) provides a comprehensive analysis of the fiscal effects of aid in Ethiopia using a unique quarterly data set for the period 1993-2008, and finds no evidence of a long-run relationship between aid and tax revenue.

Finally, recent work by Brun, Chambas and Guerineau (2009) highlights two important additional considerations within the literature. The first is the need to account for the likely problem of endogeneity. While high levels of aid (grants) may affect levels of tax collection, it may equally be that levels of tax collection in recipient countries shape aid flows, particularly with low tax collection driving higher levels of needed aid funding. Indeed, it seems evident in many cases (for example, in post-conflict settings) that aid is high precisely because recipient governments have very limited capacity to raise domestic revenue. The standard econometric response to this issue is the use of an instrumental variable for aid, thus eliminating the impact of endogeneity. 
Brun, Chambas and Guerineau (2009) correspondingly instrument for aid by constructing an index of 'aid potential', following the method proposed by Tavares (2003) and, having done so, they find a statistically significant positive effect of aid levels on tax effort within their entire sample. More recently, Benedek, Gupta and Muthoora (2012) similarly seek to account for possible endogeneity through the use of General Method of Moments (GMM) estimation techniques.

The second innovation introduced by Brun, Chambas and Guerineau (2009) is an effort, noted above, to capture the impact of aid on tax collection, contingent on the quality of institutions. Here they highlight two possible channels, as: (a) countries with weak institutions may be more susceptible to a negative impact of aid on tax collection (Azam, Devarajan and O'Connell 1999); and (b) aid may, as suggested above, affect tax performance indirectly through its effect on institutions and accountability (Knack and Rahman 2004, Amprou and Cottet 2006, Svensson,2006, Martens, Mummert, Murrell and Seabright 2002, Moore 2001, Moss, Roodman and Standley 2005). They correspondingly insert various measures of institutional and democratic quality into a standard tax effort regression and find that the impact of aid on tax effort is not affected by either corruption or democracy, but is affected by the quality of institutions. Specifically, they find that for countries with the lowest quality of bureaucracy (11 per cent on the observations in the sample) the impact of aid is negative, while for countries with stronger institutions the effect of aid is positive. This approach is partially replicated by Benedek, Gupta and Muthoora (2012), who split their sample according to institutional strength and find a stronger negative impact of aid on tax collection in weak institutional environments.

In summary, despite IMF support for the position that aid discourages tax effort, the preponderance of recent evidence reviewed above suggests that this result is not robust. Moreover, there is recent strong evidence that the impact is context-specific and dependent particularly on the quality of institutions. As important, is the need to appreciate that all of the results are subject to quite pronounced econometric and conceptual challenges, which demand that the results, while useful, be treated with some caution. 


\section{References}

Aberbach, J. and Christensen, T. (2007) 'The Challenges of Modernizing Tax Administration: Putting Customers First in Coercive Public Organizations', in Public Policy and Administration, 22 (155), 155-182

Acharya, A., de Lima, A.F. and Moore, M. (2006) 'Proliferation and fragmentation: Transaction costs and value of aid', in Journal of Development Studies, 42 (1), 1-21

Aizenman, J. and Jinjarak, Y. (2009) 'Globalisation and Developing Countries - a Shrinking Tax Base', Journal of Development Studies, 45 (5), 653-71

- (2008) 'The collection efficiency of the Value Added Tax: Theory and international evidence', in The Journal of International Trade \& Economic Development: An International and Comparative Review, 17 (3): 391- 410

Amprou, C. and Cottet, C. (2006) Aide et politique budgétaire des pays bénéficiaires: une revue de la littérature économique, Rapport thématique JUMBO 16, Paris: Agence française de développement

Ascher, W. (1989) 'Risk, Politics and Tax Reform: Lessons from Some Latin American Experiences', in M. Gillis (ed), Tax Reform in Developing Countries, Durham: Duke University Press

Azam, J-P., Devarajan, S. and O'Connell, S-A. (1999) Aid Dependence Reconsidered, Policy Research Working Paper Series 2144, Washington DC: World Bank

Baer, K., Benon, O. and Toro, J. (2002) Improving Large Taxpayers' Compliance: A Review of Country Experience, IMF Occasional Paper 215, Washington DC: International Monetary Fund

Baker, R. (2006) Capitalism's Achilles Heel: Dirty Money and How to Revive the Free-Market System, London: John Wiley and Sons

Barbone, L., Das-Gupta, A., de Wulf, L., and Hansson, A. (1999) Reforming Tax Systems: The World Bank Record in the 1990s, World Bank Policy Research Working Paper 2237, Washington DC: World Bank

Bates, R. (2001) Prosperity and Violence: The Political Economy of Development, New York: W. W. Norton \& Company

_ (1989) 'A Political Scientist Looks at Tax Reform', in M. Gillis (ed), Tax Reform in Developing Countries, Durham: Duke University Press, 473-491

Baunsgaard T. and Keen, M. (2005) Tax Revenue and (or?) Trade Liberalization, IMF Working Paper 05/112, Washington DC: International Monetary Fund

Behn, R. (2003) 'Why Measure Performance? Different Purposes Require Different Measures', in Public Administration Review 63(5): 586-606 
Benedek, D., Gupta, S. and Muthoora (2012) Foreign Aid and Revenue: Still a Crowding Out Effect?, IMF Working Paper 12/186, Washington DC: International Monetary Fund

Berenson, M. (2006) Don't Mess With Taxes! How Poles and Russians Pay Their Dues, Princeton NJ: Department of Politics, Princeton University

Bergman, M. (2003) 'Tax Reforms and Tax Compliance: The Divergent Paths of Chile and Argentina', in Journal of Latin American Studies, 35, 593-624

_ (2002) 'Who Pays for Social Policy? A Study on Taxes and Trust', in Journal of Social Policy 31 (2): 289-305

Besley, T. and Persson, T. (2010) 'State capacity, conflict, and development', in Econometrica, $78(1), 1-34$

Bird, R. (2008) Tax Challenges Facing Developing Countries, Institute for International Business Working Paper 12, Toronto: University of Toronto

_ (1992) Tax Policy and Economic Development, Baltimore: Johns Hopkins University Press

(1989) 'The Administrative Dimension of Tax Reform in Developing Countries', in M. Gillis (ed), Tax Reform in Developing Countries, Durham: Duke University Press

— and Gendron, P-P. (2007) The VAT in Developing and Transitional Countries, Cambridge: Cambridge University Press

— and Jun, J. (2005) Earmarking in Theory and Korean Practice, International Studies Program Working Paper 05-15. Atlanta: Andrew Young School of Policy Studies, Georgia State University

and Vazquez-Caro, J. (2011) Benchmarking Tax Administrations in Developing Countries: A Systemic Approach, International Studies Program Working Paper 11-04, Atlanta: Andre Young School of Policy Studies, Georgia State University

- and Zolt, E. (2005) Redistribution via Taxation: The Limited Role of the Personal Income Tax in Developing Countries, International Tax Program Paper 0508, Toronto: Joseph L. Rotman School of Management

Birdsall, N. and Savedoff, W.D. (2011) Cash on Delivery: A New Approach to Foreign Aid, Washington DC: Center for Global Development

Boesen, N. (2004) Enhancing Public Sector Capacity: What Works, What Doesn't and Why?, Washington DC: Operations Evaluation Department, World Bank

Bolnick, B. and Hadler, S. (2011) Appropriate Aid Modalities for Supporting Tax Reform, Paris: Organisation for Economic Co-operation and Development

Bourguignon, F. and Sundberg, M. (2007) 'Aid Effectiveness - Opening the Black Box', in American Economic Review 97(2) 
Boyce, J. and Forman, S. (2010) Financing Peace: International and National Resources for Post-Conflict Countries and Fragile States, World Development Report 2011 Background Paper, Washington DC: World Bank

and O'Donnell, M. (2007a) 'Peace and the Public Purse: An Introduction' in J. Boyce and M. O'Donnell (eds), Peace and the Public Purse: Building State Capacity After Violent Conflict, Boulder: Lynne Rienner

(2007b) 'Policy Implications: The Economics of Postwar Statebuilding', in J. Boyce and M. O'Donnell (eds), Peace and the Public Purse: Building State Capacity After Violent Conflict, Boulder: Lynne Rienner

Boylan (1996). 'Taxation and Transition: The Politics of the 1990 Chilean Tax Reform', Latin American Research Review, 31 (1): 7-31

Bräutigam, D. (2008) 'Taxation and State Building in Developing Countries', in D. Brautigam, O$\mathrm{H}$. Fjeldstad and M. Moore (eds), Taxation and State-building in Developing Countries: Capacity and Consent, Cambridge: Cambridge University Press

- and Knack, S. (2004) 'Foreign Aid, Institutions and Governance in Sub-Saharan Africa', in Economic Development and Cultural Change, 52, 255-285

Brun J-F., Chambas, G. and Guerineau, S. (2009) Existe-il un effet d'éviction de l'aide sur le prélèvement public? Mimeo 12

_ and Laporte, B. (2010) IMF Program and Tax Effort: What Role for institutions in Africa? CERDI Etudes and Documents 2010.33

Carnahan, M. (2007) Options for Revenue Generation in Post-Conflict Environments, Political Economy Research Institute Working Paper 137. Amherst MA: University of Massachusetts

Casanegra de Jantscher, M. (1990) 'Administering the VAT', in M. Gillis, C. Shoup and G. P. Sicat (eds), Value Added Taxation in Developing Countries, Washington DC: World Bank

Christian Aid (2010) Shifting Sands: Tax Transparency and Multinational Enterprises, London: Christian Aid

Clist, P. and Morrissey, O. (2011) 'Aid and Tax Revenue: Slgns of a Positive Effect Since the 1980s', in Journal of International Development, 23(2), 165-180

Cobham, A. (2005) Tax Evasion, Tax Avoidance and Development Finance, QEH Working Paper Number 129, Oxford: Queen Elizabeth House, Oxford University

—_ and Goodall, A. (2011) Constructing a New Global Tax Data Set: Motivation, Methodology and Opportunities, Brighton: Institute of Development Studies

Collier, P. (2006) 'Is Aid Oil? An Analysis of Whether Africa Can Absorb More Aid', in World Development, 34 (9), 1482-1497 
— Guillaumont, P., Guillaumont, S. and Gunning, J. (1997) ‘Redesigning Conditionality’, World Development, 25 (9), 1399-1407

Crandall, W. (2010) Revenue Administration: Performance Management in Tax Administration, IMF Technical Notes and Manuals, Washington DC: International Monetary Fund

Crook, R. and Booth, D. (2011) 'Conclusions: Rethinking African Governance and Development', in IDS Bulletin, 42 (2), 97-101

de Wulf, L. (2000) Reforming Tax Systems: Lessons from the 1990s, Prem Notes 37, Washington DC: World Bank

Devarajan, S., Rajkumar, A.S. and Swaroop, V. (1999) What Does Aid to Africa Finance?, Washington DC: World Bank Development Research Group

Devas, N., Delay, S. and Hubbard, M. (2001) 'Revenue Authorities: Are They the Right Vehicle for Improved Tax Administration?', in Public Administration and Development, 21 (3), 211222

Djankov, S., Montalvo, J. and Reynal Querol, M. (2009) 'Aid With Multiple Personalities', in Journal of Comparative Econometrics, 37 (2), 217-229

Dunning, T. (2004) 'Conditioning the Effect of Aid: Cold War Politics, Donor Credibility and Democracy in Africa', in International Organization, 58 (2), 409-423

Durand, F. and Thorp, R. (1998) 'Reforming the State: A Study of the Peruvian Tax Reform', in Oxford Development Studies, 26(2), 133-151

Easterly, W. (2005) 'What Did Structural Adjustment Adjust? The Association of Policies and Growth with Repeated IMF and World Bank Adjustment Loans', in Journal of Development Economics, 76 (1), 1-22

Emran, S. and Stiglitz, J. (2005) 'On Selective Indirect Tax Reform in Developing Countries', in Journal of Public Economics, 89(4), 599-623

Eubank, N. (2010) Peace-Building Without External Assistance: Lessons from Somaliland, CGD Working Paper 198, Washington DC: Center for Global Development

Factora, J (2006) 'Poverty Reduction Support Credits: A Stocktaking', in S. Koeberle, Z. Stavreski and J. Walliser (eds), Budget Support as More Effective Aid?: Recent Experiences and Emerging Lessons, Washington DC: World Bank, 47-80

Fairfield, T. (2011) Strategies for Passing Equity Enhancing Tax Reform. mimeo

- (2010) 'Business Power and Tax Reform: Taxing Income and Profits in Chile and Argentina', in Latin American Politics and Society, 52(2), 37-71

Fjeldstad, O-H. (2005) Corruption in Tax Administration: Lessons from Institutional Reforms in Uganda, CMI Working Paper 10. Bergen: Chr. Michelsen Institute

_ (2004) 'What's Trust Got To Do With It? Non-Payment of Service Charges in Local 
Authorities in South Africa', in Journal of Modern African Studies, 42 (4), 539-562

(2001) 'Taxation, Coercion and Donors: Local Government Tax Enforcement in Tanzania', in Journal of Modern African Studies, 39 (2), 289-306

- and Heggstad, K. (forthcoming) Local Government Revenue Mobilization in Anglophone Africa, ICTD Working Paper, Brighton: International Centre for Tax and Development

and Moore, M. (2008) 'Tax Reform and State-Building in a Globalized World', in D. Brautigam, O-H. Fjeldstad and M. Moore (eds), Taxation and State-Building in Developing Countries: Capacity and Consent, Cambridge: Cambridge University Press

Flores-Macías, G. (forthcoming) Financing Security Through Elite Taxation: The Case of Colombia's 'Democratic Security Taxes', ICTD Working Paper, Brighton: International Centre for Tax and Development

Frot, E. and Santiso, J. (2010) Crushed Aid: Fragmentation in Sectoral Aid, OECD Working Paper No. 284, Paris: Organisation for Economic Co-operation and Development

Gehlbach, S. (2008) Representation Through Taxation: Revenue, Politics and Development in Postcommunist States, Cambridge: Cambridge University Press

GFI (2010). Illicit Financial Flows from Africa: Hidden Resources for Development, Washington DC: Global Financial Integrity

— Illicit Financial Flows from Developing Countries: 2002-2006, Washington DC: Global Financial Integrity

Ghani, A. and Lockhart, C. (2008) Fixing Failed States: A Framework for Rebuilding a Fractured World, Oxford: Oxford University Press

Gill, J. (2000) A Diagnostic Framework for Revenue Administration, World Bank Technical Paper 472, Washington DC: World Bank

Gillis, M. (ed) (1989) Tax Reform in Developing Countries, Durham: Duke University Press

Gordon, R., (ed.) (2010) Taxation in Developing Countries: Six Case Studies and Policy Implications, New York: Columbia University Press

Gray, C. (2001) Enhancing Transparency in Tax Administration in Madagascar and Tanzania, African Economic Policy Discussion Paper 77, Washington, DC: USAID

Greenaway, D. and Morrissey, O. (1993) 'Structural Adjustment and Liberalisation in Developing Countries: What Lessons Have We Learned?', in Kyklos, 46 (2), 241-61

Grindle, M. (2007) 'Good Enough Governance Revisited', in Development Policy Review 25 (5), $553-574$

Gupta, A.S. (2007) Determinants of Tax Revenue Efforts in Developing Countries, IMF Working Paper 184. Washington DC: International Monetary Fund 
Gupta, S. (2011) Domestic Resource Mobilization, Aid Dependency and Taxation. OECD Meeting on Taxation, Statebuilding and Aid, Washington D.C: United States Agency for International Development

Clemens, B., Pivovarsky, A. and Tiongson, E. (2004) 'Foreign Aid and Revenue Response: Does the Composition of Aid Matter?', in S. Gupta, B. Clemens and G. Inchauste (eds) Helping Countries Develop: The Role of Fiscal Policy, Washington, DC: International Monetary Fund

Harberger, A. (1989) 'Lessons of Tax Reform from the Experiences of Uruguay, Indonesia, and Chile', in M. Gillis (ed) Tax Reform in Developing Countries, Durham: Duke University Press

Hassan, M. and Prichard, W. (2012) The Political Economy of Tax Reform: A Simple Analytical Framework Applied to Bangladesh, mimeo

Haufler, V. (2010) 'Disclosure as Governance: The Extractive Industries Transparency Initiative and Resource Management in the Developing World', in Global Environmental Politics, 10 (3), 53-73

Heredia, B. and Schneider, B-R. (2003) 'The Political Economy of Administrative Reform in Developing Countries: Building State Capacity', in B. Heredia and B-R. Schneider (eds), Reinventing Leviathan: The Politics of Administrative Reform in Developing Countries, Miami: University of Miami Press

IDD and Associates (2006) Evaluation of General Budget Support: Synthesis Report, Birmingham: International Development Department, University of Birmingham

IEG (2008) Public Sector Reform: What Works and Why? An IEG Evaluation of World Bank Support, Washington: World Bank

IMF (2011) Revenue Mobilization in Developing Countries, Washington DC: International Monetary Fund

ITC (2010) Mapping Survey: Taxation and Development, Eschborn: GTZ

Jibao, S., and Prichard, W. (forthcoming) Rebuilding Local Government Finances After Conflict: The Political Economy of Property Taxation in Post-Conflict Sierra Leone, ICTD Working Paper, Brighton: International Centre for Tax and Development

Jones, C., Morrissey, O. and Nelson, D. (2011) 'Did the World Bank Drive Tariff Reforms in Eastern Africa?', in World Development, 39 (3), 324-335

Keen, M. (forthcoming) 'Tax and Development - Again', in G. Zodrow and C. Fuest (eds), Taxation in Developing Countries,

_ (2008) 'VAT, Tariffs and Withholding: Border Taxes and Informality in Developing Countries', in Journal of Public Economies 92, 1892-1906

and Simone, A. (2004) 'Tax Policy in Developing Countries: Some Lessons from the 1990s and Some Challenges Ahead', in S. Gupta, B. Clements and G. Inchauste (eds), Helping 
Countries Develop: The Role of Fiscal Policy, Washington DC: International Monetary Fund, pp. 302-352

Knack, S. (2009) Sovereign Rents and the Quality of Tax Policy and Administration, World Bank Policy Research Working Paper 4773, Washington DC: World Bank

_ and Rahman, A. (2004) Donor Fragmentation and Bureaucratic Quality in Aid Recipients, Policy Research Working Paper Series 3186. Washington DC: World Bank

Koeberle, S., Bedoya, H., Silarszky, P. and Verheyen, G. (eds) (2005) Conditionality Revisited: Concepts, Experiences and Lessons, Washington DC: World Bank

Lieberman, E. (2002) Race and Regionalism in the Politics of Taxation in Brazil and South Africa, Cambridge: Cambridge University Press

Lloyd, T., McGillivray, M., Morrissey, O., and Opoku-Afari, M. (2009) 'The Fiscal Effects of Aid in Developing Countries: A Comparative Dynamic Analysis', in G. Mavrotas and M. McGillivray (eds), Development Aid: A Fresh Look, Basingstoke: Palgrave Macmillan UNU-WIDER Studies in Development Economics and Policy, 158-179

Mahdavi, S. (2008) 'The Level and Composition of Tax Revenue in Developing Countries: Evidence From Unbalanced Panel Data', in International Review of Economics and Finance, 17 (4), 607-617

Mahon, J. (2004) 'Causes of Tax Reform in Latin America, 1977-95', Latin American Research Review, 39 (1), 4-31

Marshall, J. (2009) One Size Fits All? IMF Tax Policy in Sub-Saharan Africa, Christian Aid Occasional Paper 2, London: Christian Aid

Martins, P. (2010) Fiscal Dynamics in Ethiopia: A Cointegrated VAR Model with Quarterly Data, CREDIT Research Paper 10/05, Nottingham: University of Nottingham, School of Economics

Martens, B., Mummert, U., Murrell, P. and Seabright, P. (2002) The Institutional Economics of Foreign Aid, Cambridge: Cambridge University Press

McGillivray, M. and Morrissey, O. (2004), Fiscal Effects of Aid, in T. Addison and A. Roe (eds), Fiscal Policy for Development, Basingstoke: Palgrave/WIDER, 72-96 (2001) 'Aid Illusion and Public Sector Fiscal Behaviour', in Journal of Development Studies, 37 (6), 118-136

— (2000) 'Aid Fungibility in Assessing Aid: Red Herring or True Concern?', in Journal of International Development, 12 (3), 413-428

Melo, M. (2007) 'Institutional Weakness and the Puzzle of Argentina's Low Taxation', in Latin American Politics and Society, 49 (4), 115-148

Mkandawire, T. (2010) 'On Tax Effort and Colonial Heritage in Africa', in Journal of Development Studies, 46 (10), 1647-1669 
Montinola, G. (2010) When Does Aid Conditionality Work?, in Studies in Comparative International Development, 45, 358-382

Moore, M. (2008) 'Between Coercion and Contract: Competing Narratives on Taxation and Governance', in D. Brautigam, O-H. Fjeldstad and M. Moore (eds), Taxation and State Building in Developing Countries: Capacity and Consent, Cambridge: Cambridge University Press

- (2007) How Does Taxation Affect the Quality of Governance?, IDS Working Paper 280, Brighton: Institute of Development Studies

_ (2001) 'Political Underdevelopment: What Causes "Bad Governance"?', in Public Management Review, 3 (3), 1-34

Morrissey, O. (2006) 'Fungibility, Prior Actions, and Eligibility for Budget Support', in S. Koeberle, Z. Stavreski and J. Walliser (eds), Budget Support as More Effective Aid?: Recent Experiences and Emerging Lessons, Washington DC: World Bank, 333-350

- (2005) 'Alternatives to Conditionality in Policy-Based Lending', in S. Koeberle, H. Bedoya, P. Silarszky and G. Verheyen (eds), Conditionality Revisited: Concepts, Experiences and Lessons, Washington DC: World Bank, 237-248

_ (1995) 'Political Commitment, Institutional Capacity and Tax Policy Reform in Tanzania', in World Development, 23 (4), 637-649

_ M'Amanja, D. and Lloyd, T. (2007) 'Aid and Growth in Kenya: A Time Series Analysis' in S. Lahiri (ed), Theory and Practice of Foreign Aid, Vol. 1, Amsterdam: Elsevier, 313-332

Morss, W. (1984) 'Institutional Destruction Resulting From Donor and Project Proliferation in Sub-Saharan African Countries', in World Development, 12(4), 465-470

Moss, T., Pettersson, G. and van de Walle, N. (2006) An Aid-Institutions Paradox? A Review Essay on Aid Dependency and State Building in Sub-Saharan Africa, Center for Global Development Working Paper Number 74, Washington DC, Center for Global Development

_ Roodman, D., and Standley, S. (2005) The Global War on Terror and U.S. Development Assistance: USAID Allocation by Country, 1998-2005, Center for Global Development Working Paper 62, Washington DC: Center for Global Development

Murphy, R. (2009) Information Exchange: What Would Help Developing Countries Now? London: Tax Justice Network

OECD (2010) Citizen-State Relations: Improving Governance Through Tax Reform, Paris: Organisation for Economic Co-operation and Development

- (2009) Aid Effectiveness: A Progress Report on Implementing the Paris Declaration, Paris: Organisation for Economic Co-operation and Development

- (2008) Governance, Taxation and Accountability: Issues and Practices, Paris: Organisation for Economic Co-operation and Development 
Olson, M. (1965) The Logic of Collective Action: Public Goods and the Theory of Groups, Cambridge MA: Harvard University Press

Osei, P. (2000) 'Political Liberalisation and the Implementation of Value Added Tax in Ghana', in Journal of Modern African Studies, 38 (2), 255-278

Osei, R., Morrissey, O. and Lloyd, T. (2005) 'The Fiscal Effects of Aid in Ghana', in Journal of International Development, 17 (8), 1037-1054

Ouattara, B. (2006) 'Aid, Debt and Fiscal Policies in Senegal', in Journal of International Development, 18(8), 1005-1022

Palan, R., Murphy, R. and Chavagneux, C. (2010) Tax Havens: How Globalization Really Works, Ithaca, NY: Cornell University Press

Prichard, W. (2010a) Taxation and State Building: Towards a Governance Focused Tax Reform Agenda, IDS Working Paper 341, Brighton: Institute of Development Studies

_ (2010b) Taxation, Responsiveness and Accountability in Sub-Saharan Africa, PhD Thesis, Brighton: Institute of Development Studies

- (2009) The Politics of Taxation and Implications for Accountability in Ghana 1981-2008, IDS Working Paper 330, Brighton: Institute of Development Studies

_ and Jibao, S. (2010) Building a Fair, Transparent and Inclusive Tax System in Sierra Leone, Freetown: Christian Aid Sierra Leone

— and Leonard, D. (2010) 'Does Reliance on Tax Revenue Build State Capacity in subSaharan Africa?', in International Review of Administrative Sciences, 76 (4), 653-675

Remmer, K. (2004) 'Does Foreign Aid Promote the Expansion of Government?', in American Journal of Political Science, 48 (1), 77-92

Rieffel, L. and Fox, J. (2008) The Millennium Challenge Corporation: An Opportunity for the Next President, Brookings Global Economy and Development Working Paper 30, Washington DC: Brookings Institute

Roodman, D. (2006) Aid Project Proliferation and Absorptive Capacity, Center for Global Development Working Paper 75, Washington DC: Center for Global Development

Sanchez, O. (2006) 'Tax Systems Reform in Latin America: Domestic and International Causes', in Review of International Political Economy, 13 (5), 772-801

Severino J-M. and Ray, O. (2009) The End of ODA: Death and Rebirth of a Global Public Policy, CGDEV Working Paper No. 167, Washington DC: Center for Global Development

Stevens, M. and Teggeman, S. (2004) 'Comparative Experience with Public Service Reform in Ghana, Tanzania and Zambia', in S. Kpundeh and B. Levy (eds), Building State Capacity in Africa: New Approaches, Emerging Lessons, Washington DC: World Bank Institute 
Svensson, J. (2006) Absorption Capacity and Disbursements Constraints, paper presented at the third AFD/EUDN Conference 'Financing development: the challenges of a twofold increase', Paris, December

_ (2003) 'Why Conditional Aid Does Not Work and What Can Be Done About It?', in Journal of Development Economics, 70, 381-402

Tavares, J. (2003) ‘Does Foreign Aid Corrupt?', in Economic Letters, 79, 99-106

Teera, J. and Hudson, J. (2004) 'Tax Performance: A Comparative Study', in Journal of International Development, 16 (6), 785-802

Therkildsen, O. (2004) 'Autonomous Tax Administration in Sub-Saharan Africa: The Case of the Uganda Revenue Authority', in Forum for Development Studies, 31(1), 59-88

Thirsk, W. (1997) Tax Reform in Developing Countries. Washington DC: World Bank

TJN (2009) Tax Information Exchange Agreements, Tax Justice Briefing, London: Tax Justice Network

_ (2008) Country-By-Country-Reporting: How to Make Multinational Companies More Transparent, Tax Justice Briefing, London: Tax Justice Network

van de Walle, N. (2005) Overcoming Stagnation in Aid-Dependent Countries. Washington DC: Center for Global Development

van Soest, C. (2007a) 'How Does Neopatrimonialism Affect the African State's Revenues? The Case of Tax Collection in Zambia', in The Journal of Modern African Studies, 45 (4), 621 645

(2007b) Donor Support to Tax Administration Reform in Africa: Experiences in Ghana, Tanzania, Uganda and Zambia, German Federal Ministry for Economic Cooperation and Development/German Development Institute

Williamson, T. (2006) 'General Budget Support and Public Financial Management Reform: Emerging Lessons from Tanzania and Uganda', in S. Koeberle, Z. Stavreski and J. Walliser (eds), Budget Support as More Effective Aid?: Recent Experiences and Emerging Lessons, Washington DC: World Bank, 139-151

World Bank (2012) An Integrated Assessment Model for Tax Administration, Washington DC: World Bank

_ (1981) Accelerated Development in Sub-Saharan Africa, Washington DC: World Bank 


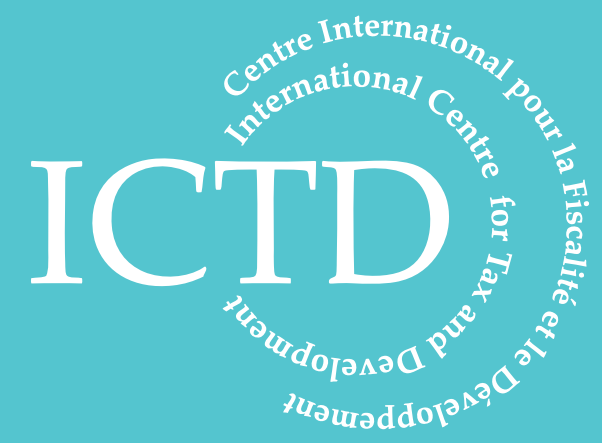

International Centre for Tax and Development at the Institute of Development Studies

Brighton BN1 9RE, UK

T: +44 (0)1273606261

F: $+44(0) 1273621202$

E: info@ictd.ac

www.ictd.ac 